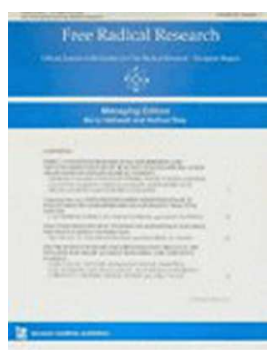

\title{
Damage of DNA and proteins by major lipid peroxidation products in genome stability
}

\begin{tabular}{|r|l|}
\hline Journal: & Free Radical Research \\
\hline Manuscript ID: & GFRR-R-2011-0362.R1 \\
\hline Manuscript Type: & Review \\
\hline Date Submitted by the Author: & n/a \\
\hline Keywords: List of Authors: & $\begin{array}{l}\text { Tudek, Barbara; Institute of Biochemistry and Biophysics, PAS, Department } \\
\text { of Molecular Biology; Warsaw University, Institute of Genetics and } \\
\text { Biotechnology } \\
\text { Winczura, Alicja; Institute of Biochemistry and Biophysics, PAS,, } \\
\text { Department of Molecular Biology } \\
\text { Zdzalik, Daria; Warsaw University, Institute of Genetics and Biotechnology }\end{array}$ \\
\hline & \\
\hline
\end{tabular}

\section{SCHOLARONE}

Manuscripts 
Barbara Tudek, Ph.D.

Warsaw, 13 January 2012

e-mail: tudek@ibb.waw.pl

Prof. Michael Davies

Re Ms: GFRR-R-2011-0362

Editor,

Free Radical Research

Email: daviesm@ hri.org.au

Dear Prof. Davies,

Thank you very much for considering our manuscript GFRR-R-2011-0362 for publication in Free Radical Research

"Lipid peroxidation induced damage of DNA and proteins in genome stability" by Winczura et. al.

We would like to thank the reviewers for their valuable comments. Enclosed, please find the revised version, which includes answers to all questions raised by the reviewers. We changed the text and table presentation according to reviewers recommendations. All changes are marked in the text in red.

Sincerely yours

Barbara Tudek 
Answer to comments of Reviewer 1:

1. There are a number of abbreviations used in the text which it would be helpful to add to the Abbreviations list at the beginning of the document (e.g. M1dG, M1dA, AcrdG, CrodG, BER, NER, MDA, HNA, DHN, NSCLC).

We included suggested abbreviations as well as added several new to the List of Abbreviations.

2. Page 4, 3rd line of text. There should, presumably be a closing ) and full stop after "[formula 1]".

Corrected.

3. Page 4: it should perhaps be also noted that lipid hydroperoxides can be directly reduced, in a two-electron process, to the corresponding alcohols by species such as glutathione peroxidase-4.

We included this suggestion into the final text on p. 5. bottom.

4. Page 4, second paragraph. The second and third lines may be clearer if reworded as follows ...." undergoes cyclization to a cyclised peroxyl radical .... [formula 5], which can undergo further reactions to form unstable peroxides and a series of unstable oxidised fatty acid products (Fig. 1. [formula 6 and 7])

We simplified this paragraph according to the suggestion of the reviewer.

5. Page 4, second paragraph, last line: converts the lipid peroxyl radicals into a relatively stable lipid hydroperoxides [7,10].

Corrected

6. Page 5, section 3: it would be very helpful for the reader if data on the approximate levels of HNE, peroxides and related species were given. This is of critical importance in evaluating cell studies where these materials are added in, often at huge levels that are clearly not pathologically relevant. It is important that new workers in the field, do not succumb to using levels that are clearly inappropriate.

On p. 6 we added a paragraph about the levels of lipid hydroperoxides and TBARS in human blood plasma and lymphocytes.

7. Page 6. This reviewer is not a fan of single sentence paragraphs. To my mind it would be better if the various small paragraphs written here were linked together in a single paragraph.

We linked together small paragraphs previously slightly changing composition of this part of the final text. 
8. Page 7, line 7 of section 4: export of this complex from the cell...

Corrected

9. Page 10, penultimate line: the sentence "It is suggested that they derive from HNE..." needs a reference.

Reference added.

10. Page 14, section 8: as above, some absolute estimates as to the levels / abundance of these materials in pathological specimens would be very helpful and useful (fold increases are interesting - as given in Table 1, but the absolute values are more valuable and useful).

Absolute values of ethenoadducts levels found in pathological specimens were included as a new column to the Table 1.

11. The reference section needs to be re-formatted in the style of the journal (e.g. list all authors, text not in bold, etc.

The reference section was reformatted.

\section{Answer to comments of Reviewer 2:}

1. The authors mostly presented about HNE and MDA, even though the title is "Lipid peroxidation ---". There are a lot of lipid peroxides, and each one gives different adduct. It may be better to improve the title.

We agree that there are plethora of LPO products, and we were unable to describe all of them. However, the consequences of the major LPO products were described. That is why we changes the title to the following:

"Damage of DNA and proteins by major lipid peroxidation products in genome stability"

2. Keywords in the first page are not same as in the title page.

Corrected

3. Figure 6: The legend should be " by malondialdehyde products" but not "by LPO products".

Legend was changed to "The major exocyclic DNA adducts" 


\title{
Damage of DNA and proteins by major lipid peroxidation products in
} genome stability

\author{
Alicja Winczura ${ }^{1}$, Daria Zdżalik ${ }^{2}$, Barbara Tudek ${ }^{1,2}$ * \\ ${ }^{1}$ Institute of Biochemistry and Biophysics, Polish Academy of Sciences, Pawińskiego 5a, 02- \\ 106 Warsaw, Poland; \\ ${ }^{2}$ Institute of Genetics and Biotechnology, Warsaw University, Pawińskiego 5a, 02-106 \\ Warsaw, Poland. \\ *Corresponding author: Barbara Tudek, \\ Institute of Biochemistry and Biophysics, \\ Polish Academy of Sciences, \\ Pawińskiego 5a, \\ 02-106 Warsaw, Poland \\ tel: (+4822) 592-3334; fax: (+4822) 592-2190 \\ e-mail: tudek@ibb.waw.pl
}

Key words: HNE; DNA repair; lipid peroxidation; DNA-adducts

\begin{abstract}
Abbreviations: Acr-dG, acrolein deoxyguanosine adduct; BER, Base Excision Repair; Cro$\mathrm{dG}$, crotonaldehyde deoxyguanosine adduct; DHN, 1,4-dihydroxy-2-nonene; $\varepsilon \mathrm{A}, 1, N^{6}$ ethenoadenine; $\varepsilon \mathrm{C}, 3, N^{4}$-ethenocytosine; $1, N^{2}-\varepsilon \mathrm{G}, 1, N^{2}$-ethenoguanine; $N^{2}, 3 \varepsilon \mathrm{G}, N^{2}, 3$ ethenoguanine; EH, 2,3-epoxy-4-hydroxynonanal; ER, endoplasmic reticulum; Et-ethyl
\end{abstract}


group; HNA, 4-hydroxy-2-nonenoic acid; HNE, trans-4-hydroxy-2-nonenal; LPO, lipid

peroxidation; M1dA, $\mathrm{N}^{6}$-(3-oxopropenyl)-2'-deoxyadenosine; M1dG, pirymido-[1,2a]purine-

10(3H)-one-2'-deoxyribose; MDA, malondialdehyde; Me-methyl group; NER, Nucleotide

Excision Repair; NSCLC, non-small cell lung cancer 


\begin{abstract}
Oxidative stress and lipid peroxidation (LPO) accompanying infections and chronic inflammation may induce several human cancers. LPO products are characterized by carbohydrate chains of different length, reactive aldehyde groups and double bonds, which make these molecules reactive to nucleic acids, proteins and cellular thiols. LPO-derived adducts to DNA bases form etheno-type and propano-type exocyclic rings, which have profound mutagenic potential, and are elevated in several cancer-prone diseases. Adducts of long chain LPO products to DNA bases inhibits transcription. Elimination from DNA of LPO-induced lesions is executed by several repair systems: base excision repair (BER), direct reversal by AlkB family proteins, nucleotide excision repair (NER) and recombination. Modifications of proteins with LPO products may regulate cellular processes like apoptosis, cell signaling and senescence. This review summarizes consequences of LPO products presence in cell, particularly 4-hydroxy-2-nonenal in terms of genomic stability.
\end{abstract}




\section{Introduction}

Living organisms undergo permanent exposition to damaging agents which may arise from environmental and endogenous processes. Damaging agents react with all cellular components, including proteins, lipids and nucleic acids. It has been estimated that every day approximately 20000 DNA lesions originating from endogenous sources are formed in every cell of the human organism. Several mechanisms participate in the generation of DNA modifications, namely deamination, spontaneous hydrolysis of the N-glycosidic bond, alkylation and activity of free radicals, which include reactive oxygen (ROS) and nitrogen species (RNS), and lipid peroxidation (LPO) products [1-3]. However, ROS, RNS and, LPO products play a dual role in cells. At low or moderate concentrations they are mediators of specific physiological processes. High concentrations can be detrimental to all components of the cell. Overproduction of oxygen species combined with insufficiency in protective mechanisms of anti-oxidative defense is defined as oxidative stress [4, 5].

DNA damage caused by free radicals is probably the most heterogeneous group of DNA lesions due to the wide variety of deleterious molecules produced in cells in the conditions of oxidative stress. Free radicals can be generated by irradiation (X rays, $\gamma$-rays, UV light), drugs or heat; however, most of them are formed in normal metabolic processes that occur in every cell [4-6].

This paper will focus on lipid peroxidation, interaction of LPO products with DNA and proteins and biological consequences of these processes.

\section{Lipid Peroxidation}

A growing body of evidence suggests that many of the detrimental cellular effects observed under oxidative stress conditions are mediated by the products of lipid degradation [7]. Particularly susceptible to peroxidation are polyunsaturated fatty acids (PUFA) as they 
possess a number of double bonds. Lipid peroxidation occurs in three phases, initiation, propagation and termination [8]. In the initiation phase an oxidant abstracts a hydrogen atom from a C-H bond of lipid to generate carbon-centered lipid radical (Fig.1 [formula 1]). In the propagation phase carbon-centered radical reacts with $\mathrm{O}_{2}$ to form peroxyl radical (Fig. 1 [formula 3]). Peroxyl radical may further react with another molecule of PUFA and abstract a hydrogen atom from the fatty acid chain. This feature leads to propagation of the chain reaction of lipid peroxidation. As a result, a single initiation reaction can generate hundreds of lipid peroxides of different structures. For example, if the peroxyl radical exists at one of the two ends of the double-bond (Fig. 1 [formula 2]), it is reduced to hydroperoxide (Fig. 1 [formula 4]). Conjugated diene hydroperoxides (Fig. 1 [formula 4]) are stable in the absence of metals. Metal complexes and metalloproteins abundant in cells can reduce all fatty acid hydroperoxides to alkoxyl radicals, which subsequently undergo multiple chemical reactions to generate broad range of products, depending on the chemical structure of the precursor lipid [9].

If the peroxyl radical is at the internal position in the fatty acid chain (Fig. 1 [formula 3]) it undergoes cyclization to a cyclised peroxyl radical (Fig. 1 [formula 5]), which can undergo further reactions to form a series of unstable oxidized fatty acids (Fig. 1 [formula 6 and 7]). These fatty acids give rise to final products, like isoprostanes and malondialdehyde (MDA) [9]. LPO is terminated when the chain reaction is interrupted by a reaction of lipid radical with another lipid radical or lipid peroxide with a molecule of antioxidant, which provides the hydrogen atom that converts the lipid peroxyl radicals into a relatively stable lipid hydroperoxides [7, 10].

Lipid hydroperoxides may undergo further reactions and rearrangements. They can be directly reduced to the corresponding alcohols by e.g. glutathione peroxidase GPx4, which was reported as a major cellular enzyme dedicated for lipid hydroperoxides scavenging [11, 
12]. Alternalively, lipid hydroperxides give rise to several other groups of molecules that include smaller derivatives of the original molecule. These short chain reactive aldehydes are relatively stable and can diffuse throughout the whole cell attacking other biomolecules. Short chain reactive aldehydes are classified into the following families: 2-alkenals (e.g. acrolein, crotonaldehyde, 2-hexenal), 4-hydroxy-2-alkenals (e.g. 4-hydroxy-2-hexenal - HHE, 4hydroxy-2-nonenal - HNE) and ketoaldehydes (e.g. malondialdehyde - MDA, glyoxal, 4-oxo2-nonenal - ONE) [7] (Fig. 2). Multiplicity of LPO products is tremendously augmented by the existence of stereoisomers of several of these compounds.

Concentrations of reactive aldehydes usually vary depending on the tissue analysed, health status and age of examined organism. In solid tissues the level is usually an order of magnitude or more higher than in blood plasma [20]. In blood serum of breast cancer women the level of plasma lipid hydroperoxides $(\mathrm{LH})$ ranged from 0.12 to $1.85 \mu \mathrm{M}$ whereas plasma TBARS (Thiobarbituric Acid Reactive Substances, well-established method for monitoring lipid peroxidation) ranged from 3.09 to $6.84 \mu \mathrm{M}$ [13]. TBARS in healthy children ranged from 1.22 to $1.36 \mu \mathrm{M}$ [14] whereas in another study TBARS in healthy male subjects ranged from 0.5 to $2.2 \mu \mathrm{M}$ (average $1.2 \pm 0.3 \mu \mathrm{M}$ ) in sera whereas average level of lipid hydroperoxides was $3.9 \pm 1.5 \mu \mathrm{M}$ (range 1.9- 6.9) in sera [15]. The other study determined the levels of MDA in lymphocytes obtained from healthy subjects grouped according to the age. The average MDA level was $12.35 \pm 0.37 \mathrm{nmol} / \mathrm{mg}$ protein in the group of young persons (11-20 years old) and increased with age reaching the highest average value of $33.63 \pm 0.42$ $\mathrm{nmol} / \mathrm{mg}$ protein in the group of elderly persons (51-60 years) [16].

\section{HNE as a prevalent LPO product and its reactivity}

Among numerous products of lipid peroxidation two major and most extensively studied are malondialdehyde (MDA) and 4-hydroxy-2-nonenal (HNE). One of the possible 
pathways of MDA formation is presented in Fig. 1. The best known consequences of MDA presence in cells are MDA interactions with nucleic acids and induction of mutations (described below). However, best described in respect of protein modification, changing gene transcription, and cell signaling is HNE. Although probably all LPO products interact with proteins and may affect cell metabolism, knowledge of the resulting consequences is mostly based on reactions of HNE.

HNE is generated from $\omega 6$ PUFA, mainly during non-enzymatic peroxidation of linoleic acid and arachidonic acid. In a study using 9 and 13 hydroperoxides of linoleic acid (13-hydroxyperoxy-octadecenoic acid (13(S)-HPODE) and 9-hydroxyperoxy-octadecenoic acid (9(R)-HPODE)) as initial material, it was shown that two distinct mechanisms may lead to the formation of HNE. Hydrogen abstraction from C8 of 13(S)-HPODE and subsequent cleavage of the resulting 10, 13-dihydroperoxide between C9 and C10 gives 4(S)-HPNE (4hydroperoxy-2-nonenal). Cleavage of 9(R)-HPODE forms 3Z-nonenal, which is a precursor of 4(R,S)-HPNE. Subsequent simple reduction step of 4-HPNE leads to HNE formation (Fig. 3) $[7,17]$.

Apart from uncontrolled radical-derived pathway of HNE formation, a certain amount of this compound may be generated via enzymatic reactions. Two most important enzymes are lipooxygenases (LOX) and cyclooxygenases (COX), which oxidize arachidonic acid to form mediators of inflammation, prostaglandins, prostacyclins or leukotrienes. The finding that $15 \mathrm{LOX}$ isoform oxidizes linoleates exclusively to 13(S)-HPODE, a precursor for HNE, has led to inclusion of these enzymes in the group of potential factors enhancing LPO [18, 19].

$\mathrm{HNE}$ is an amphiphilic compound with three functional chemical groups, which determine its reactivity. Interplay of the double $\mathrm{CC}$ bond, carbonyl group (CO) and hydroxyl 
group $(\mathrm{OH})$ provides partially positive charge at carbon 3 and carbon 1, which are the sites of nucleophilic attack by other compounds (e.g., thiols or amino groups).

HNE can be involved in two types of chemical reactions. It may undergo Michael addition reaction with biomolecules containing amino and/or thiol groups like cysteine, lysine, the imidazole group of histidine or glutathione (Fig. 4), as well as it can form Schiffbase with primary amines (e.g., lysine) (Fig 5) [10]. The latter reaction is competitive with Michael addition. Nevertheless, within cells, HNE may contribute to cross-linking of proteins. The reaction of Schiff base formation between HNE and lysine of a particular protein followed by the second reaction of Michael addition with a lysine of another protein results in binding of two proteins [10]. Reactivity of HNE with proteins and nucleic acids, which are the primary targets for HNE, determines its biological effects in cell. HNE forms adducts to side chains of Cys, His and Lys in proteins. Among them the most reactive with HNE is Cys, which undergoes HNE addition two and three orders of magnitude more efficiently than His and Lys, respectively [20]. However, the exact site of modification of proteins by HNE is determined not only by the reactivity, but also by additional factors like polarity of microenvironment, tertiary structure of protein or accessibility of the side chain to HNE. There is a plethora of data documenting protein modification by HNE in vitro and in vivo. HNE targets a variety of oxidoreductases, transferases, hydrolases, lyases, kinases, ion channels and many other proteins. In general, HNE adducts to proteins diminish their activity, although some examples of activation are also known [20].

\section{Biological effect of $\mathrm{HNE}$}

Intracellular concentration of HNE may range from submicromolar, usually $0.1-3 \mu \mathrm{M}$, in blood plasma under physiological conditions, up to $5 \mathrm{mM}$ under conditions of oxidative stress in cellular compartments adjacent to membranes. Concentration of HNE in cell is 
mostly regulated by a coordinated function of glutathione-S-transferases (mainly by GSTA4-4 and hGST5.8 isoforms) and the RLIP76 transporter. Glutathione-S-transferases (GSTs) catalyze conjugation of HNE to glutathione (GSH), whereas RLIP76 is engaged in ATPdependent export of this complex from the cell [21]. HNE-GSH transfer is the most rapid and effective way of HNE neutralization, but HNE can also be metabolized by aldehyde dehydrogenase to corresponding carboxylic acid - HNA (4-hydroxy-2-nonenoic acid), and alcohol dehydrogenase to corresponding alcohol - DHN (1,4-dihydroxy-2-nonene) [22]. The proportion between these three metabolites in rat hepatocytes was 6:4:1 for HNE-GSH: HNA: DHN respectively [23].

Although cells are equipped with tools that prevent uncontrolled action of HNE, under conditions of oxidative stress defense mechanisms seem to be insufficient to maintain cellular homeostasis. HNE was shown to be a ubiquitous molecule that could very easily diffuse along all cellular compartments in a much more effective way than "oxygen mediators", like hydrogen peroxide that acted mainly in the cytosol [24]. HNE at 0.1-10 $\mu \mathrm{M}$, close to physiological concentrations in blood plasma, stimulates cellular proliferation, reduces differentiation and activates cytoprotective response. It activates JNK and p38 kinases which are known to act in response to cellular stresses and are members of the MAPK family that transduces signals through phosphorylation cascades $[25,26]$. It also activates tyrosine kinase receptors (RTKs), such as EGF and PDGF receptors [27, 28] and protein kinase C [29]. At high concentrations, HNE is cytotoxic and shows its detrimental potential to cellular compounds. Proteins are the primary targets for HNE, as it was reported that adducted proteins are the second most abundant group of HNE-derivatives, just after HNE-GSH, HNA and DHN metabolites. Proteins moderately modified with HNE are degraded in the proteasome, whereas extensive modification leading to protein cross-links may result in the formation of large aggregates that inhibit proteasome [30]. On the other hand, HNE may also 
directly inhibit proteasome, however, such effect was observed only at very high (1 $\mathrm{mM}$ and higher) HNE concentrations [31]. High HNE concentrations also influence signaling pathways, but usually the effects of its activity are different from those observed at physiological doses. For example, at high concentrations HNE induces apoptosis through the death receptor Fas, TP53 and liberation of cytochrome c from mitochondrial membranes [32]. Generally, HNE introduced into eukaryotic cells exhibits pleiotropic effects depending on the concentration and the cell type.

HNE also alters gene expression. In microarray experiments RKO cells treated with HNE responded by induction or downregulation of hundreds of genes. Among them, genes responsible for antioxidant response, heat shock and ER stress displayed the most significant changes in the quantity of transcripts. Nevertheless, transcription of genes whose products are engaged in many other processes, like cell signaling, apoptosis, cell cycle regulation or transcription regulation, was also influenced by HNE. This demonstrates that HNE simultaneously affects multiple cellular pathways, which in consequence gives rise to a complex response of the cell [32-34].

\section{Modification of DNA bases by LPO products and their processing by DNA polymerases}

Directly oxidized DNA bases, for years were considered major, harmful DNA lesions. It is now clear that modifications generated by LPO products may contribute to DNA damage to nearly the same extent as directly oxidized bases. There are distinct groups of linear and cyclic LPO specific DNA lesions.

Malondialdehyde reacts in DNA with guanine, adenine and cytosine to form cyclic pirymido-[1,2 $\alpha$ ]purine-10(3H)-one-2'-deoxyribose $\left(\mathrm{M}_{1} \mathrm{dG}\right)$ adduct and linear N6-(3oxopropenyl)-2'-deoxyadenosine $\left(\mathrm{M}_{1} \mathrm{dA}\right)$ and N4-(3-oxopropenyl)-2'-deoxycytosine $\left(\mathrm{M}_{1} \mathrm{dC}\right)$ 
adducts, respectively [9]. $\mathrm{M}_{1} \mathrm{dG}$ (Fig. 6) is the major MDA-DNA adduct and was detected in human and rodent tissues. In E. coli cells, it induces transversions to $\mathrm{T}$ and transitions to A with a frequency comparable with that of 8-oxoG [4].

Exocyclic propano DNA adducts are formed by the attachment of LPO product that generates additional saturated, six-membered ring in a DNA base. These adducts are derived from the reaction of DNA with acrolein, crotonaldehyde and HNE. Acr-dG, Cro-dG and HNE-dG were found in rodent and human tissues [35, 36].

Etheno DNA adducts (Fig. 6) posses five-membered exocyclic rings attached to DNA bases. The exact pathway of their formation in vivo is not known, although it is clear that they may be generated in vitro by the exposition of DNA to lipid peroxides. Ethenoadducts are also introduced into DNA by certain environmental carcinogens like vinyl chloride or its metabolite, chloroacetaldehyde (CAA) [37].

Propano- and etheno-type adducts that are found in native mammalian DNA are unsubstituted and substituted with side chains of different length, depending on the structure of reacting LPO product. For example, HNE may directly interact with guanosine, adenosine, cytidine and thymidine moiety in DNA. Michael addition, followed by Schiff base formation by $\mathrm{HNE}$ aldehyde group leads to formation of $1 N^{2}$-propanodeoxygunosine (Fig. 7) and plethora of $\mathrm{HNE}$ adducts to $\mathrm{C}, \mathrm{A}$ and $\mathrm{T}$. Thymine adducts are linear, due to the fact that thymine is deprived of exocyclic amino group. HNE and other LPO adducts to G, C and A are cyclic in nucleosides, nucleotides and single-stranded DNA. In double stranded DNA the reaction of aldehyde group is reversible. This results in the appearance of linear adducts, which are flexible and may be tolerated to some degree by DNA polymerases [38], on one hand, and on the other may form new Schiff base linkage with the amino- groups of nucleic acids and amino acids to create inter- and intra-strand DNA-DNA cross-links and DNAprotein crosslinks. In the presence of oxygen HNE unergoes epoxidation and reacts with $\mathrm{G}, \mathrm{C}$ 
or A moieties in DNA that leads to ethenoadducts formation, substituted with heptyl side chains [10, 39] (Fig. 8).

In vitro reaction of $\mathrm{HNE}$ with DNA bases is of different efficiency. $\mathrm{dG}$ and $\mathrm{dC}$ are primary targets, while dA reacts with much lower efficiency, and HNE adducts to dT are in minority [39]. Etheno-type adduct of HNE to guanosine, $1, N^{2} \varepsilon$-guanosine, and propano-type cyclic $1, \mathrm{~N}^{2}$-propanodeoxyguanine were shown to occur as four diastereoisomers of tetracyclic structure (purine condensed with ethano and furano rings) [40, 41]. These isomers were shown to have different mutagenic potency [42]. Other cyclic DNA adducts deriving from acrolein and crotonaldehyde occur in stereomeric forms as well [43, 44].

There is a lot of controversies concerning formation of unsubstituted etheno-DNA adducts. It is suggested that they derive from HNE [45, 46]. In oxidizing conditions HNE may form small amounts of unsubstituted etheno-DNA adducts, however the available data from in vitro studies are not consistent. Chen and Chung [45] demonstrated that under oxidizing conditions the ratio of unsubstituted to substituted ethenoadenine is $6: 100$, of unsubstituted to substituted guanine equals 24:100, and the number of unsubstituted ethenoadducts is significantly decreased under nitrogen. However, our previous in vitro studies showed that in oxidizing conditions only guanosine yielded unsubstituted $1, N^{2}-\varepsilon \mathrm{dG}$, and only in the amount of 1-2 \% of modified dG [39]. Unsubstituted ethenoadducts are formed from unsaturated fatty acids in animals and humans [47], however the exact pathway of their formation is not clear. One suggested possibility of $1, N^{2}-\varepsilon \mathrm{dG}$ formation is from HNE precursor, 4-hydroperoxy-2nonenal (HPNE) [48].

\section{Sequence-specificity in the formation of exocyclic-DNA adducts and repair kinetics}

Specific sequences in DNA, which favour formation of tertiary structures containing single-stranded fragments, e.g. palindromic loops, cruciforms and GC-rich sequences may be 
particularly susceptible to formation of exocyclic DNA adducts. Studies of Chung and coworkers [49] have shown that in human cells HNEdG adducts were formed preferentially in the third guanine residue of the codon 249 of TP53 gene. This site was found to be a mutational hot-spot in numerous types of human cancers [50], which shows that tertiary DNA structure is of importance in the induction of DNA damage and/or its repair. It cannot be also excluded that LPO accompanies the development of different types of cancer, and that its fingerprint stays in DNA in the form of mutations in specific sequences.

We also studied in vitro sequence-specific interaction of the vinyl -chloride metabolite chloroacetaldehyde (CAA) with human TP53 gene exons 5-8, using DNA Polymerase Fingerprint Analysis (DPFA), and identified sites of the highest sensitivity for modification using ethenoadducts-specific DNA glycosylases [51]. CAA-induced DNA damage was more extensive in TP53 regions which revealed secondary structure perturbations, and were localized in regions of mutation hot-spots. These perturbations inhibited DNA synthesis on undamaged template as well, suggesting that they may be the fragile sites for acquisition of mutations due to the easier induction of lesions in these DNA sequences and/or substitution of replicative DNA polymerases with DNA polymerases of lower fidelity, which incorporate non-cognate nucleotides [52].

Choudhury and coworkers [40] established that the half time of elimination of trans-4hydroxynonenal-induced cyclic $1, \mathrm{~N}^{2}$-propanodeoxyguanine DNA adducts by HeLa cells nuclear extract was $3 \mathrm{~h}$ in $30^{\circ} \mathrm{C}$. This repair was performed by nucleotide excision repair system, as the extracts from XPA deficient cells did not eliminate the lesion from DNA. Interestingly, repair was stereospecific, two stereoisomers were removed from DNA more efficiently that the other two.

\section{Translesion synthesis of exocyclic-DNA adducts and their mutagenic potency}


The presence of unsubstituted etheno-adducted DNA bases in the template relatively mildly inhibits DNA synthesis by replicative and damage-specific DNA polymerases, while substituted etheno-type and propano-type cyclic adducts pose a strong barrier for replication $[53,54]$

Ethenoadducts are mutagenic, however prokaryotic and eukaryotic DNA polymerases may behave differently when replicating DNA containing ethenoadducts. In bacteria, $1, N^{6}$ ethenoadenine is mostly recognized as unmodified adenine by DNA polymerases, and infrequently (about $0.1 \%$ ), even under SOS conditions (conditions of decreased replication fidelity caused by production of the elevated amounts of damage specific DNA polymerases of the $\mathrm{Y}$ family), gives rise to $\mathrm{A}: \mathrm{T} \rightarrow \mathrm{G}: \mathrm{C}$ transitions [55] or $\mathrm{A}: \mathrm{T} \rightarrow \mathrm{T}: \mathrm{A}$ and $\mathrm{A}: \mathrm{T} \rightarrow \mathrm{C}: \mathrm{G}$ transversions, as well as to one-nucleotide deletions [56]. In contrast, in simian kidney (COS) cells $70 \%$ of $\varepsilon A$ residues in DNA are replicated erroneously, giving rise to $63 \%$ of $\mathrm{A}: \mathrm{T} \rightarrow \mathrm{G}: \mathrm{C}$ transitions and to only $7 \%$ of other base-pair substitutions [56]. Mutagenic specificity of $\varepsilon$ A depends also on its position on leading and lagging strand during DNA replication. In human HeLa cells A:T $\rightarrow$ T:A transversions were the most frequent (7\%) on the leading strand, although $\mathrm{A}: \mathrm{T} \rightarrow \mathrm{C}: \mathrm{G}$ and $\mathrm{A}: \mathrm{T} \rightarrow \mathrm{G}: \mathrm{C}$ base pair substitutions were also numerous (5\% and $2 \%$, respectively) [57].

Ethenocytosine in site-directed mutagenesis experiments in E. coli and mammalian cells gave rise to 1.5 or $2 \%$ of targeted mutagenic events in non SOS-induced E. coli cells [55, 58], 30\% in SOS-induced ones, and $81 \%$ in simian kidney cells $[58,59]$. The predominant mutations generated by $\varepsilon \mathrm{C}$ in both $E$. coli and COS cells were $\mathrm{C}: \mathrm{G} \rightarrow \mathrm{A}: \mathrm{T}$ transversions and $\mathrm{C}: \mathrm{G} \rightarrow \mathrm{T}:$ A transitions.

$N^{2}$,3-ethenoguanine induced G:C $\rightarrow$ A:T transitions and 1, $N^{2}$-ethenoguanine induced $\mathrm{G}: \mathrm{C} \rightarrow \mathrm{A}: \mathrm{T}, \mathrm{G}: \mathrm{C} \rightarrow \mathrm{T}: \mathrm{A}$ and $\mathrm{G}: \mathrm{C} \rightarrow \mathrm{C}: \mathrm{G}$ base-pair substitutions both in primer extension 
assays with purified DNA polymerases and in E. coli cells [60-62]. Additionally, $1, N^{2}-\varepsilon \mathrm{G}$ generated in vitro one- and two-nucleotide deletions [63].

Treatment of mammals with compounds inducing etheno DNA adducts, additionally triggers chromosomal aberrations and recombination [64]. It was shown that $\varepsilon A$ when present in DNA strongly stimulates the activity of topoisomerase II, causing DNA strand breaks [65].

Substituted LPO-derived cyclic DNA adducts, like HNE-DNA adducts strongly inhibit DNA synthesis by prokaryotic and eukaryotic DNA polymerases both in vitro and in cellular models $[38,39]$. In bacteria HNE increased the mutation rate in the lacZ gene of M13 phage transfected into wild type $E$. coli strain. The most frequent events were recombinations, base substitutions and frameshifts. Over $50 \%$ of base substitutions were $\mathrm{C} \rightarrow \mathrm{T}$ transitions followed by $\mathrm{G} \rightarrow \mathrm{C}$ and $\mathrm{A} \rightarrow \mathrm{C}$ transvertions, which suggests that $\mathrm{HNE}$ adducts to all DNA bases are a source of point mutations, as well as trigger recombination events [38, 39]. In E. coli $\mathrm{HNE}$ induces the SOS system [66] with low fidelity DNA polymerases, Pol IV and Pol V, which can bypass different DNA lesions, thus enabling the cell to survive under stress conditions. The third SOS E. coli DNA polymerase, Pol II, is the enzyme of high fidelity. Detailed analysis of the contribution of SOS DNA polymerases in the induction of mutations on HNE damaged templates revealed that Pol IV can bypass HNE-DNA adducts in an error-free manner. Pol II and Pol V are strongly blocked by the presence of these adducts. The infrequent bypass by Pol II is error-free, while by Pol V is error-prone. Both Pol II and Pol IV can compete with Pol V decreasing mutation rate on HNE-adducted templates [67].

Cooperation of low-fidelity DNA polymerases in bypassing HNE-DNA adducts was also observed in eukaryotic cells. Pol $\mathrm{l}$ was able to incorporate correctly matched nucleotide opposite the HNE-dG adduct, although it was not able to elongate the synthesized DNA strand and fell off the template. Pol $\kappa$, in turn, could elongate the HNE-dG:dC pair, which ensured further DNA synthesis [54]. In this way the HNE-dG adducts were bypassed by two 
damage-specific DNA polymerases in an error-free manner. This may, at least partially explain the fact that HNE is the least mutagenic LPO product, however due to the fact that it is also able to modify proteins, the most cytotoxic [20].

\section{LPO-induced DNA damage in human pathological processes}

Constantly growing body of evidence indicates that LPO products are engaged in human pathology. Much of these data is devoted specifically to HNE and different aspects of its reactivity. Measurements of protein adducts, DNA adducts and levels of free HNE in human blood and tissues were performed. Presently there are nearly forty human diseases (neurodegenerative, hepatic, cardiovascular, metabolic and many others) in which increased HNE steady state levels have been detected [20].

\subsection{Exocyclic-DNA adducts, oxidative stress and cancer}

The most abundant LPO-derived DNA adducts like propanoadducts to guanine and, to a lesser extent, ethenoadducts, were found in many tissues of rodents and humans as background DNA lesions [68]. However, there are also examples that in some conditions DNA ethenoadducts can be generated in the organism above the basic levels. Accumulation of DNA ethenoadducts was reported in LEC rats, in which copper dependent induction of oxidative stress via Fenton reaction occurs [69]. Similarly, an increase in ethenoadducts levels was correlated with oxidative stress in OXYS rats overproducing ROS [70], and was reported in spleen of SJL mice stimulated to overproduce nitric oxide (6-fold elevated for both $\varepsilon$ A and $\varepsilon \mathrm{C}$ lesions) [71]. The most recent paper on this issue reports that in SJL mice inflammation model, lipid peroxidation derived DNA lesions dominate over DNA oxidation and DNA deamination products. Importantly, DNA ethenoadducts ( $\varepsilon \mathrm{A}$ and $\left.1, N^{2}-\varepsilon \mathrm{G}\right)$ were found to be elevated 3-4 fold not only in organs that were targeted by inflammatory processes, but also in 
kidneys, which are not directly affected by the inflammation. It was concluded that oxidative and nitrosative stresses associated with inflammation can affect tissues at a distance from the activated macrophages responsible for NO overproduction during chronic inflammation [72].

Oxidative stress and LPO-derived DNA damage can play an important role in cancer development, especially in cancers where inflammatory processes are a characteristic component of their etiopathogenesis [73]. In the animal model positive correlation between the level of ethenoadduct DNA lesions and lipoxygenase-catalyzed metabolites of arachidonic acid was established in the study on multistage mouse skin carcinogenesis [74]. Since then, numerous studies showed that in several human diseases predisposing to cancer, the levels of ethenoadducts in cancer prone tissues were elevated (Table 1)

From the clinical perspective all these diseases are associated with chronic inflammatory processes and high risk of cancer development. On the molecular level they are considered as malfunctions that lead to oxidative stress in cells of the targeted organ.

Currently it is postulated that persistent oxidative stress and lipid peroxidation induced by inflammation, metal storage diseases and unbalanced diet lead to accumulation of DNA lesions from endogenous sources. Under conditions of chronic and long term occurrence of these risk factors, perpetuation of carcinogenesis or progression of cancer to full malignancy is possible $[75,76]$.

\section{Repair of LPO derived DNA lesions}

DNA is under permanent control of several defense systems, which have been developed to protect the genome from mutagenic modifications. DNA repair systems are specialized in repair of almost all possible damages, and the choice of the repair pathway depends on the structure of the damage. Bulky adducts are repaired by Nucleotide Excision Repair pathway (NER) [77], double strand breaks and interstrand cross-link may be processed 
by Non Homologous End Joining (NHEJ) or Homologous Recombination (HR) [78], whereas most of the small DNA lesions are repaired by the Base Excision Repair or by direct reversal (alkyltransferases, dioxygenases) [79].

In repair of LPO-induced DNA damage probably all above-mentioned DNA repair systems are engaged. This is due to a variety of the types of DNA lesions induced by LPO products.

\subsection{Repair of etheno-DNA adducts by BER enzymes}

BER is a DNA repair pathway dedicated to processing of small base lesions derived from oxidation and alkylation that cause only little distortion in the DNA helix. In a classical view it consists of five steps: (I) lesion recognition, (II) excision of the damaged base, (III) AP site incision and removal of the chemical residues that could block further steps of the pathway, (IV) incorporation of the proper nucleotide(s) by DNA polymerases and (V) ligation of the DNA strand to restore the original DNA molecule [80-83].

Damaged bases are recognized by DNA glycosylases. Glycosylases are specialized enzymes capable of processing a wide range of oxidative and alkylated bases. Presently, 13 human DNA glycosylases with different, but partially overlapping substrate specificity have been identified. Several are engaged in repair of etheno-DNA adducts. All of them are monofunctional DNA glycosylases, and excise damaged base leaving behind an abasic (AP) site. AP site is subsequently recognized by the next enzyme in the BER pathway, APendonuclease, which cleaves phosphodiester bond 5' to the AP site initiating further repair steps, deoxyribose excision, filling the gap and ligation.

$\varepsilon \mathrm{A}$ is excised by alkylpurine-DNA- $N$-glycosylase (ANPG) [84], whereas $\varepsilon \mathrm{C}$ by thymine-DNA-glycosylase (TDG); the latter also excises thymine from G:T pairs, resulting from deamination of 5-methylcytosine [85]. Ethenocytosine is also excised by single-stranded 
uracil DNA glycosylase, SMUG1 [86] and by MBD4 glycosylase, although activity of the latter is strongly limited to $\mathrm{CpG}$ islands [87, 88].

ANPG glycosylase has a wide substrate specificity, and besides $\varepsilon$ A excises from DNA also 1, $N^{2}$-ethenoguanine [89], hypoxanthine and the alkylated bases, 3-methyladenine and 7methylguanine [84]. TDG excises $\varepsilon \mathrm{C}, \mathrm{T}$ and $\mathrm{U}$ from pairs with guanine, and its activity is strongly stimulated by the next enzyme in the BER pathway, AP-endonuclease, APE1 [90]. TDG and APE1 also play the role of transcription regulators [91-94]

Ethenocytosine repair by the BER system is dependent not only on the level and activity of TDG, MBD4 or SMUG1 DNA glycosylases, but also on the presence and/or activity of ANPG glycosylase, which primary substrate is $\varepsilon$ A. ANPG binds strongly to DNA containing $\varepsilon \mathrm{C}$, and although does not excise this modified base, does not allow its excision by the proper $\varepsilon \mathrm{C}$ glycosylase, like TDG [95]. This may explain observation that the level of $\varepsilon \mathrm{C}$ measured in different human tissues was constantly higher than that of $\varepsilon \mathrm{A}$ [96].

\subsubsection{Repair of etheno-DNA adducts by BER system and human cancers}

We compared repair of $\varepsilon \mathrm{A}, \varepsilon \mathrm{C}$ and 8-oxoguanine (8-oxoG) in polymorphic blood leukocytes of non-small cell lung cancer (NSCLC) patients and healthy volunteers. The major histological subtypes of NSCLC are squamous cell carcinoma (SQ), which ethiology is strongly linked to tobacco smoking, and adenocarcinoma (AD), which is related to chronic inflammations, infections and healing of scars, although, the majority of lung cancer patients in Western countries are tobacco smokers or past smokers. The most striking finding of the study was observation that blood leukocytes repair capacity for $\varepsilon A$ and 8-oxoG was significantly lower in lung cancer patients than in healthy volunteers [97, 98]. Consistently, 8oxoG level in cancer patients leukocytes was higher than that in healthy controls. This showed that deficient repair of oxidative DNA damage may be a risk factor for the development of 
lung cancer. Surprisingly, $\varepsilon$ C repair rate was the same in the leukocytes of cancer patients and healthy controls. However, in individuals developing $\mathrm{AD}, \varepsilon \mathrm{C}$ repair was significantly decreased. Also, $\varepsilon$ A repair activity was markedly lower in the leukocytes of AD patients than in SQ patients and healthy controls. Comparing repair rates in lung tissues of cancer patients, similar differences were observed between histological types of cancer. $\varepsilon \mathrm{A}$ and $\varepsilon \mathrm{C}$-repair activities were significantly lower in normal lung of individuals suffering from AD than from SQ. Interestingly, no such differences were observed in repair rates of 8-oxoguanine. This suggests that the etiology of lung adenocarcinoma may be related to inefficient repair of exocyclic DNA adducts, deriving from lipid peroxidation. Very few other studies have linked LPO with the progression of lung cancer, and our study showed, for the first time, the association between the deficiency of specific repair pathways for $\varepsilon \mathrm{A}$ and $\varepsilon \mathrm{C}$ with the development of specific histological type of tumor.

No difference in $\varepsilon \mathrm{A}$ and $\varepsilon \mathrm{C}$ level between tumor and non-affected lung tissues was recorded, and this could be due to compensating increase of repair activities in the tumor. No significant differences in $\varepsilon \mathrm{A}$ and $\varepsilon \mathrm{C}$ level as well as repair activities were associated with age, gender and smoking habit.

Thus results obtained in that study suggested that oxidative stress contributes to induction and/or progression of lung cancer, and that repair deficiency for $\varepsilon \mathrm{A}$ and $\varepsilon \mathrm{C}$ is associated particularly with the development of lung adenocarcinoma.

Similarly, $\varepsilon A$ and $\varepsilon C$ repair rates were decreased in PBL of colorectal carcinoma (CRC) patients in comparison to healthy controls, suggesting that such decreased repair rate could be one of the risk factors for CRC development [99]. Indeed, inflammation and high fat diet are the major risk factors for CRC development. Surprisingly, $\varepsilon \mathrm{A}$ and $1, N^{2}-\varepsilon \mathrm{G}$ level was also lower in PBL of CRC patients than in healthy controls. This could suggest that apart from the BER system, ethenoadducts are eliminated from DNA by other repair activities, 
which are induced in cancer patients. Good candidates are dioxygenases of AlkB family. Their level was significantly increased in some types of cancer e.g. prostate cancer [100, 101] however their contribution to repair of exocyclic DNA adducts in mammals still is not clear.

\subsubsection{Oxidative dealkylation by AlkB enzymes}

It was demonstrated that AlkB protein from Escherichia coli, which removes alkyl groups by direct reversal without DNA scission and resynthesis, repairs also $\varepsilon A$ and $\varepsilon C$ [102104]. Cellular functions of numerous members of this group of enzymes is poorly elaborated, and it is not well understood to what extent they participate in repair of exocyclic DNA adducts. The data obtained for E. coli suggest that in this bacteria AlkB is at least as important as BER in the elimination of etheno-type, unsubstituted exocyclic DNA adducts [105].

Dioxygenases from AlkB family remove alkyl groups from DNA by oxidative dealkylation in the reaction, which requires oxygen, 2-oxoglutarate and $\mathrm{Fe}^{2+}$ ions $[2,106] . E$. coli AlkB protein catalyses oxidation of cytotoxic alkyl groups in ssDNA, dsDNA as well as in RNA, which leads to the reconstitution of intact base and liberation of oxidized alkyl group, e.g. formaldehyde or glyoxal (Fig. 9) [2]. The main DNA lesions repaired by E. coli AlkB protein are $1 \mathrm{MeA}$ and $3 \mathrm{MeC}$, but the enzyme also repairs $1 \mathrm{MeG}, 3 \mathrm{MeT}$, as well as removes ethyl, propyl, hydroxypropyl groups and etheno-groups from exocyclic DNA adducts, $\varepsilon A$ and $\varepsilon C[104,107-109]$. The enzyme removes also alkyl groups from mRNA and tRNA [110].

AlkB proteins were found in most organisms from RNA viruses to humans. In silico search revealed the existence of nine AlkB homologues in human genome, ABH1-8 [111] and the product of human obesity gene, FTO [112]. Biological functions of these proteins are not completely understood, however hABH1, hABH2, hABH3 and FTO were proven to have 
enzymatic activities dealkylating DNA or RNA [113]. ABH2 and ABH3 similarly to AlkB dealkylate $1 \mathrm{MeA}, 3 \mathrm{MeC}, 1 \mathrm{MeG}, 1 \mathrm{MeT}$ and 1-EtA in DNA, and ABH3 repairs RNA as well $[106,114,115]$. The best substrate for $\mathrm{ABH} 3$ is $3 \mathrm{MeC}$ and this lesion is preferentially repaired in ssDNA $[106,116]$. $\mathrm{ABH} 2$ eliminates more efficiently $1 \mathrm{MeA}$ than $3 \mathrm{MeC}$, and repair is more efficient when the lesion is localized in dsDNA than in ssDNA [114]. hABH2 eliminates also $\varepsilon A$ from ds and ssDNA [117], and thus may be a backup enzyme for ANPG glycosylase. Recently, it was shown that hABH2 repairs $\varepsilon \mathrm{C}$, as well, and probably competes with ANPG in the access to the lesion, since ANPG inhibits in vitro repair of $\varepsilon \mathrm{C}$ by $\mathrm{ABH} 2$ [118]. It is, however necessary to stress, that repair of etheno-DNA adducts by AlkB proteins is much less efficient than repair of methylated bases. $\mathrm{ABH} 2$ was found in replication foci, and contains a motif to bind PCNA [119]. The function of $\mathrm{ABH} 2$ might be to clean the template or alternatively participate in replication regulation.

$\mathrm{ABH} 2$ and $\mathrm{ABH} 3$ knockout mice are viable with phenotype similar to that of the wild type animals. ABH2 knockout mice accumulate $1 \mathrm{MeA}$ with age [120]. However, no accumulation of $\varepsilon \mathrm{A}$ was found both in $\mathrm{ABH} 2$ and $\mathrm{ABH} 3$ deficient mice. In contrast, a significant increase of $\varepsilon$ A level was observed in DNA of ANPG deficient mice [120]. This suggests that in spite of the possibility to repair $\varepsilon \mathrm{A}$ in vitro, in vivo $\mathrm{ABH} 2$ is not able to cope with endogenously formed $\varepsilon$ A.

$\mathrm{ABH} 1$ is a mitochondrial protein and removes $3 \mathrm{MeC}$ from ssDNA and RNA [121]. Recent studies suggest that ABH1 may also possess a lyase activity [122].

FTO dealkylates $3 \mathrm{MeT}$ and $3 \mathrm{MeU}$ in ssDNA and RNA [123], as well as $N^{6}-\mathrm{MeA}$ in ssDNA and RNA [124]. It is suggested that in higher eukaryotes FTO may be a major enzyme, which removes methyl group from $N^{6}-\mathrm{MeA}$ in mRNA.

ABH8 besides 2-oxoglutarate/ $\mathrm{Fe}^{2+}$-dependent dioxygenase domain contains also RNA binding domain and methyltransferase domain. The protein is a tRNA methyltransferase 
required for the final step in the biogenesis of 5-methoxycarbonyl-methyluridine (mcm5(U)). The interaction of ALKBH8 with a small accessory protein, TRM112, is required to form a functional tRNA methyltransferase [125]. $\mathrm{mcm} 5(\mathrm{U})$ is frequently found in the wobble position of uridine, and may change the efficiency of translation of certain proteins [126]. Dioxygenase activity of $\mathrm{ABH} 8$ participates in hydroxylation of $\mathrm{mcm} 5(\mathrm{U})$ and its derivative 5methoxycarbonylmethyl-2-thiouridine (mcm5s2U) to yield 5-(S)-[methoxycarbonyl(hydroxy)methyl]uridine ((S)-mchm5U) [127].

AlkB proteins may also play divergent roles not related to modification of nucleic acids. $\mathrm{ABH} 1$ homologue participates in differentiation of trophoblast stem cells and in the epigenetic regulation of transcription [128]. ABH3 was recognized as prostate cancer antigen 1 (PCA-1), and many studies suggest that $\mathrm{ABH} 3$ may be a selective marker for malignant transformation in prostate [100]. Recently, it was observed that PCA-1 increases expression of Discoidin Domain Receptor 1, a receptor with tyrosine kinase activity, and in consequence promotes prostate cancer development [129].

The function of other human AlkB homologues is obscure. Their mRNA is quite abundant in most tissues, particularly in testis, which suggests that these proteins may play a role in cell differentiation, division or other important functions, and that their role is not limited to DNA repair [130].

\subsubsection{Nucleotide excision repair and recombination}

Bulky LPO adducts to DNA bases, like HNE adducts, which have alkyl side chains are repaired by nucleotide excision repair system (NER). Chung and coworkers $[49,131]$ showed that HNE-dG adducts are recognized and excised from DNA by bacterial UvrABC excinuclease. HNE-dG adducts were also more cytotoxic and mutagenic in NER deficient human and E. coli cells than in NER proficient cells [132]. Subsequent studies in E.coli, 
which used M13 phage model showed that HNE adducts to all DNA bases are efficiently repaired by E. coli NER system, however in NER deficient strain a huge increase of recombination events was observed [38], and mutation frequency increased significantly. This suggested that both NER and recombination are engaged in the elimination of deleterious effects of the presence of HNE-DNA adducts in genetic material. Interestingly, in E. coli strains deficient in repair by NER and recombination the survival of M13 phage modified with HNE was higher and mutation frequency lower than in the single uvrA mutant, suggesting the presence of a backup repair system operating in the absence of NER and recombination repair. The contribution of mismatch repair was excluded [38]. Next studies [67] showed that SOS DNA polymerases may play a role of such a backup system, since Pol IV and Pol II synthesized DNA faithfully on HNE damaged template in E. coli cells (see paragraph 7).

Contribution of recombination in repair of HNE-DNA adducts in mammalian cells was reported already in the 90-ties, since HNE was shown to induce micronuclei, sister chromatid exchanges and chromosomal aberrations [133-135].

Since most LPO-derived DNA adducts, like HNE-DNA adducts are able to form interstrand DNA cross-links [136], other repair systems, namely Fanconi anemia pathway may be engaged in repair of these DNA damages. This, however, needs further research.

We have also shown that the presence of bulky HNE-DNA adducts in the template strongly inhibits transcription by T7 RNA polymerase, and HeLa cells extract in vitro [137]. In contrast, unsubstituted $\varepsilon$ A did not inhibit RNA synthesis [138]. Treatment of wild type cells with 1-20 $\mu \mathrm{M}$ HNE caused dephosphorylation of the Cockayne syndrome complementation group B (CSB) protein. Such dephosphorylation stimulates its ATPase activity of the CSB protein necessary for transcription-coupled repair (TCR), a quick NER subpathway that preferentially removes lesions from transcribed DNA strand. The deficiency of CSB protein 
leads to progressive multisystem degeneration and premature aging [139]. Cell lines expressing CSB protein mutated in different ATPase domains exhibited different sensitivities to HNE. The motif II mutant, which binds ATP, but is defective in ATP hydrolysis was as sensitive to HNE as CSB-null cells. In contrast, motif V mutant cells were as sensitive to HNE as were the cells bearing wild type protein, while motif VI mutant cells showed intermediate sensitivity to HNE. These mutants exhibit decreased ATP binding, but retain residual ATPase activity. In addition, CSB-deficient cells were hypersensitive to physiological concentrations of HNE, and developed a higher level of sister chromatid exchanges in comparison to the wild type cells [137]. These results strongly suggest that HNE-DNA adducts are endogenous DNA lesions, blocking transcription in mammalian cells and are processed by the TCR system. Thus, HNE, and possibly other LPO products, might also be endogenously formed compounds contributing to accelerated aging and degeneration. Indeed, increased level of HNE accumulation was observed in brain tissue and in cerebrum of patients suffering from several neurodegenerative disorders like Alzheimer's, Parkinson's, Pick's, amyotrophic lateral sclerosis and Huntington diseases [140]. Interestingly, large amounts of HNE-modified proteins were found in the brains (globus pallidus) of Cockayne syndrome patients [141].

DNA repair proteins may also be targeted by LPO products, however, literature data on this issue are rather limited. Feng and coworkers [142] have shown that treatment of cells with HNE inhibits elimination of UV dimers and benzo[a]pyrenediol epoxide-guanine adducts from DNA, suggesting that NER may be inhibited in mammalian cells by elevated HNE concentrations. We have also demonstrated that high HNE concentrations (100-200 $\mu \mathrm{M})$ inhibit in vitro ATPase activity of the CSB protein as well as the transcription machinery in HeLa cell-free extracts [137]. Inhibition of cellular repair capacity by LPO products may be an important, additional mechanism of pro-carcinogenic consequences of inflammation. 


\section{Conclusions}

Lipid peroxidation generates plethora of reactive aldehydes, which are relatively stable and bind to nucleic acids, proteins and cellular thiols. As far as mutagenic properties were shown for the majority of etheno- and propano-type adducts to DNA bases, the adverse effects of LPO on human health remains controversial. Etheno-DNA adducts were elevated in cancer-prone human diseases, and carcinogenic properties were described for chemical compounds introducing ethenoadducts to DNA bases, e.g. vinyl chloride. Adducts to DNA bases of longer LPO products, like HNE, very efficiently block transcription by prokaryotic and eukaryotic transcription machineries, and may favor cell senescence, and possibly aging of organisms and neurodegenerative processes. In addition, HNE binds to proteins, and may change cellular transcription and signaling and this may depend on compound concentration. At high concentrations HNE inhibits repair of bulky adducts, which may be introduced to DNA by UV light, several environmental carcinogens, like benzo[a]pyrene, as well as LPO products, this way sensitizing cells to other mutagenic and carcinogenic exposures. On the other hand, increased HNE levels in cells also promote apoptotic signaling, while at decreased concentration, below its basal constituted levels, HNE promotes proliferation. It was shown that by blocking detoxification of HNE through the inhibition of RLIP76 catalyzed transport of glutathione-HNE out of the cell, a complete remission of many human cancer xenografts in mice was achieved [143]. HNE was also shown to inhibit telomerase activity in colon carcinoma cell lines [144] and in human leukemic cells [145]. This occurred by the reduction of GSH content, and by the modulation of expression and activity of transcription factors belonging to the Myc/Mad/Max network. Since the presence of PUFAs in the diet exposes epithelial colon cells to HNE, this aldehyde could contribute to cell growth control through the inhibitory action on telomerase activity and its expression, suggesting a protective effect 
on colon mucosa. Understanding of these processes in future may contribute to the improvement of cancer therapy.

\section{Acknowledgments}

This work was supported by Polish-French grant project 346/N-INCA/2008/0.

\section{References}

[1] Lindahl T. Instability and decay of the primary structure of DNA. Nature 1993;362:709715

[2] Sedgwick B, Bates PA, Paik J, Jacobs SC, Lindahl T. Repair of alkylated DNA: recent advances. DNA Repair (Amst) 2007;6:429-442

[3] Tudek B, Winczura A, Janik J, Siomek A, Foksinski M, Olinski R. Involvement of oxidatively damaged DNA and repair in cancer development and aging. Am J Transl Res $2010 ; 2: 254-284$

[4] Valko M, Rhodes CJ, Moncol J, Izakovic M, Mazur M. Free radicals, metals and antioxidants in oxidative stress-induced cancer. Chem Biol Interact 2006;160:1-40

[5] Valko M, Leibfritz D, Moncol J, Cronin MT, Mazur M, Telser J. Free radicals and antioxidants in normal physiological functions and human disease. Int J Biochem Cell Biol $2007 ; 39: 44-84$

[6] Valko M, Izakovic M, Mazur M, Rhodes CJ, Telser J. Role of oxygen radicals in DNA damage and cancer incidence. Mol Cell Biochem 2004;266:37-56

[7] Uchida K. 4-Hydroxy-2-nonenal: a product and mediator of oxidative stress. Prog Lipid Res $2003 ; 42: 318-343$

[8] Burcham PC. Genotoxic lipid peroxidation products: their DNA damaging properties and role in formation of endogenous DNA adducts. Mutagenesis 1998;13:287-305 
[9] Marnett LJ. Lipid peroxidation-DNA damage by malondialdehyde. Mutat Res $1999 ; 424: 83-95$

[10] Schaur RJ. Basic aspects of the biochemical reactivity of 4-hydroxynonenal. Mol Aspects Med 2003;24:149-159

[11] Brigelius-Flohe R. Glutathione peroxidases and redox-regulated transcription factors. Biol Chem 2006;387:1329-1335

[12] Yoo MH, Gu X, Xu XM, Kim JY, Carlson BA, Patterson AD, Cai H, Gladyshev VN, Hatfield DL. Delineating the role of glutathione peroxidase 4 in protecting cells against lipid hydroperoxide damage and in Alzheimer's disease. Antioxid Redox Signal 2010;12:819-827

[13] Vieira FG, Di Pietro PF, Boaventura BC, Ambrosi C, Rockenbach G, Fausto MA, Crippa CG, Da Silva EL. Factors associated with oxidative stress in women with breast cancer. Nutr Hosp 2011;26:528-536

[14] Krzystek-Korpacka M, Salmonowicz B, Boehm D, Berdowska I, Zielinski B, Patryn E, Noczynska A, Gamian A. Diagnostic potential of oxidative stress markers in children and adolescents with type 1 diabetes. Clin Biochem 2008;41:48-55

[15] Katalinic V, Salamunic I, Pazanin S, Mulic R, Milisic M, Ropac D. The antioxidant power and level of lipid peroxidation products in the sera of apparently healthy adult males. Coll Antropol 2007;31:165-171

[16] Gautam N, Das S, Mahapatra SK, Chakraborty SP, Kundu PK, Roy S. Age associated oxidative damage in lymphocytes. Oxid Med Cell Longev 2010;3:275-282

[17] Schneider C, Tallman KA, Porter NA, Brash AR. Two distinct pathways of formation of 4-hydroxynonenal. Mechanisms of nonenzymatic transformation of the 9- and 13hydroperoxides of linoleic acid to 4-hydroxyalkenals. J Biol Chem 2001;276:20831-20838 [18] Schneider C, Pratt DA, Porter NA, Brash AR. Control of oxygenation in lipoxygenase and cyclooxygenase catalysis. Chem Biol 2007;14:473-488 
[19] Noguchi N, Yamashita H, Hamahara J, Nakamura A, Kuhn H, Niki E. The specificity of lipoxygenase-catalyzed lipid peroxidation and the effects of radical-scavenging antioxidants. Biol Chem 2002;383:619-626

[20] Poli G, Schaur RJ, Siems WG, Leonarduzzi G. 4-hydroxynonenal: a membrane lipid oxidation product of medicinal interest. Med Res Rev 2008;28:569-631

[21] Yang Y, Sharma R, Sharma A, Awasthi S, Awasthi YC. Lipid peroxidation and cell cycle signaling: 4-hydroxynonenal, a key molecule in stress mediated signaling. Acta Biochim Pol 2003;50:319-336

[22] Esterbauer H, Schaur RJ, Zollner H. Chemistry and biochemistry of 4-hydroxynonenal, malonaldehyde and related aldehydes. Free Radic Biol Med 1991;11:81-128

[23] Siems WG, Zollner H, Grune T, Esterbauer H. Metabolic fate of 4-hydroxynonenal in hepatocytes: 1,4-dihydroxynonene is not the main product. J Lipid Res 1997;38:612-622 [24] Jung T, Engels M, Kaiser B, Grune T. Distribution of oxidized and HNE-modified proteins in U87 cells. Biofactors 2005;24:165-170

[25] Parola M, Robino G, Marra F, Pinzani M, Bellomo G, Leonarduzzi G, Chiarugi P, Camandola S, Poli G, Waeg G, Gentilini P, Dianzani MU. HNE interacts directly with JNK isoforms in human hepatic stellate cells. J Clin Invest 1998;102:1942-1950

[26] Uchida K, Shiraishi M, Naito Y, Torii Y, Nakamura Y, Osawa T. Activation of stress signaling pathways by the end product of lipid peroxidation. 4-hydroxy-2-nonenal is a potential inducer of intracellular peroxide production. J Biol Chem 1999;274:2234-2242 [27] Suc I, Meilhac O, Lajoie-Mazenc I, Vandaele J, Jurgens G, Salvayre R, Negre-Salvayre A. Activation of EGF receptor by oxidized LDL. Faseb J 1998;12:665-671 [28] Robino G, Parola M, Marra F, Caligiuri A, De Franco RM, Zamara E, Bellomo G, Gentilini P, Pinzani M, Dianzani MU. Interaction between 4-hydroxy-2,3-alkenals and the 
platelet-derived growth factor-beta receptor. Reduced tyrosine phosphorylation and downstream signaling in hepatic stellate cells. J Biol Chem 2000;275:40561-40567

[29] Chiarpotto E, Domenicotti C, Paola D, Vitali A, Nitti M, Pronzato MA, Biasi F, Cottalasso D, Marinari UM, Dragonetti A, Cesaro P, Isidoro C, Poli G. Regulation of rat hepatocyte protein kinase $\mathrm{C}$ beta isoenzymes by the lipid peroxidation product 4-hydroxy-2,3nonenal: A signaling pathway to modulate vesicular transport of glycoproteins. Hepatology $1999 ; 29: 1565-1572$

[30] Grune T, Davies KJ. The proteasomal system and HNE-modified proteins. Mol Aspects Med 2003;24:195-204

[31] Okada K, Wangpoengtrakul C, Osawa T, Toyokuni S, Tanaka K, Uchida K. 4-Hydroxy2-nonenal-mediated impairment of intracellular proteolysis during oxidative stress. Identification of proteasomes as target molecules. J Biol Chem 1999;274:23787-23793 [32] Awasthi YC, Sharma R, Sharma A, Yadav S, Singhal SS, Chaudhary P, Awasthi S. Selfregulatory role of 4-hydroxynonenal in signaling for stress-induced programmed cell death. Free Radic Biol Med 2008;45:111-118

[33] Liu W, Akhand AA, Kato M, Yokoyama I, Miyata T, Kurokawa K, Uchida K, Nakashima I. 4-hydroxynonenal triggers an epidermal growth factor receptor-linked signal pathway for growth inhibition. J Cell Sci 1999;112 ( Pt 14):2409-2417

[34] West JD, Marnett LJ. Alterations in gene expression induced by the lipid peroxidation product, 4-hydroxy-2-nonenal. Chem Res Toxicol 2005;18:1642-1653

[35] Chenna A, Iden CR. Characterization of 2'-deoxycytidine and 2'-deoxyuridine adducts formed in reactions with acrolein and 2-bromoacrolein. Chem Res Toxicol 1993;6:261-268 [36] Chenna A, Rieger RA, Iden CR. Characterization of thymidine adducts formed by acrolein and 2-bromoacrolein. Carcinogenesis 1992;13:2361-2365 
[37] Barbin A, Bartsch H, Leconte P, Radman M. Studies on the miscoding properties of 1,N6-ethenoadenine and 3,N4-ethenocytosine, DNA reaction products of vinyl chloride metabolites, during in vitro DNA synthesis. Nucleic Acids Res 1981;9:375-387

[38] Janowska B, Komisarski M, Prorok P, Sokolowska B, Kusmierek J, Janion C, Tudek B. Nucleotide excision repair and recombination are engaged in repair of trans-4-hydroxy-2nonenal adducts to DNA bases in Escherichia coli. Int J Biol Sci 2009;5:611-620 [39] Kowalczyk P, Ciesla JM, Komisarski M, Kusmierek JT, Tudek B. Long-chain adducts of trans-4-hydroxy-2-nonenal to DNA bases cause recombination, base substitutions and frameshift mutations in M13 phage. Mutat Res 2004;550:33-48

[40] Choudhury S, Pan J, Amin S, Chung FL, Roy R. Repair kinetics of trans-4hydroxynonenal-induced cyclic 1,N2-propanodeoxyguanine DNA adducts by human cell nuclear extracts. Biochemistry 2004;43:7514-7521

[41] Sodum RS, Chung FL. Stereoselective formation of in vitro nucleic acid adducts by 2,3epoxy-4-hydroxynonanal. Cancer Res 1991;51:137-143

[42] Fernandes PH, Wang H, Rizzo CJ, Lloyd RS. Site-specific mutagenicity of stereochemically defined 1,N2-deoxyguanosine adducts of trans-4-hydroxynonenal in mammalian cells. Environ Mol Mutagen 2003;42:68-74

[43] Zhang S, Balbo S, Wang M, Hecht SS. Analysis of acrolein-derived 1,N2propanodeoxyguanosine adducts in human leukocyte DNA from smokers and nonsmokers. Chem Res Toxicol 2011;24:119-124

[44] Stein S, Lao Y, Yang IY, Hecht SS, Moriya M. Genotoxicity of acetaldehyde- and crotonaldehyde-induced 1,N2-propanodeoxyguanosine DNA adducts in human cells. Mutat Res 2006;608:1-7

[45] Chen HJ, Chung FL. Formation of etheno adducts in reactions of enals via autoxidation. Chem Res Toxicol 1994;7:857-860 
[46] Nair J, Nair UJ, Sun X, Wang Y, Arab K, Bartsch H. Quantifying etheno-DNA adducts in human tissues, white blood cells, and urine by ultrasensitive (32)P-postlabeling and immunohistochemistry. Methods Mol Biol 2011;682:189-205

[47] Bartsch H, Nair J. Accumulation of lipid peroxidation-derived DNA lesions: potential lead markers for chemoprevention of inflammation-driven malignancies. Mutat Res $2005 ; 591: 34-44$

[48] Lee SH, Arora JA, Oe T, Blair IA. 4-Hydroperoxy-2-nonenal-induced formation of 1,N2-etheno-2'-deoxyguanosine adducts. Chem Res Toxicol 2005;18:780-786

[49] Chung FL, Pan J, Choudhury S, Roy R, Hu W, Tang MS. Formation of trans-4-hydroxy2-nonenal- and other enal-derived cyclic DNA adducts from omega-3 and omega-6 polyunsaturated fatty acids and their roles in DNA repair and human p53 gene mutation. Mutat Res 2003;531:25-36

[50] Tudek B, Kowalczyk P, Ciesla JM. Localization of chloroacetaldehyde-induced DNA damage in human p53 gene by DNA polymerase fingerprint analysis. IARC Sci Publ $1999 ; 279-293$

[51] Kowalczyk P, Ciesla JM, Saparbaev M, Laval J, Tudek B. Sequence-specific p53 gene damage by chloroacetaldehyde and its repair kinetics in Escherichia coli. Acta Biochim Pol 2006;53:337-347

[52] Goodman MF. Error-prone repair DNA polymerases in prokaryotes and eukaryotes. Annu Rev Biochem 2002;71:17-50

[53] Hang B, Chenna A, Guliaev AB, Singer B. Miscoding properties of 1,N6-ethanoadenine, a DNA adduct derived from reaction with the antitumor agent 1,3-bis(2-chloroethyl)-1nitrosourea. Mutat Res 2003;531:191-203 
[54] Wolfle WT, Johnson RE, Minko IG, Lloyd RS, Prakash S, Prakash L. Replication past a trans-4-hydroxynonenal minor-groove adduct by the sequential action of human DNA polymerases iota and kappa. Mol Cell Biol 2006;26:381-386

[55] Basu AK, Wood ML, Niedernhofer LJ, Ramos LA, Essigmann JM. Mutagenic and genotoxic effects of three vinyl chloride-induced DNA lesions: 1,N6-ethenoadenine, 3,N4ethenocytosine, and 4-amino-5-(imidazol-2-yl)imidazole. Biochemistry 1993;32:12793-12801 [56] Pandya GA, Moriya M. 1,N6-ethenodeoxyadenosine, a DNA adduct highly mutagenic in mammalian cells. Biochemistry 1996;35:11487-11492

[57] Levine RL, Yang IY, Hossain M, Pandya GA, Grollman AP, Moriya M. Mutagenesis induced by a single 1,N6-ethenodeoxyadenosine adduct in human cells. Cancer Res 2000;60:4098-4104

[58] Moriya M, Zhang W, Johnson F, Grollman AP. Mutagenic potency of exocyclic DNA adducts: marked differences between Escherichia coli and simian kidney cells. Proc Natl Acad Sci U S A 1994;91:11899-11903

[59] Palejwala VA, Simha D, Humayun MZ. Mechanisms of mutagenesis by exocyclic DNA adducts. Transfection of M13 viral DNA bearing a site-specific adduct shows that ethenocytosine is a highly efficient RecA-independent mutagenic noninstructional lesion. Biochemistry 1991;30:8736-8743

[60] Singer B, Kusmierek JT, Folkman W, Chavez F, Dosanjh MK. Evidence for the mutagenic potential of the vinyl chloride induced adduct, N2, 3-etheno-deoxyguanosine, using a site-directed kinetic assay. Carcinogenesis 1991;12:745-747

[61] Langouet S, Mican AN, Muller M, Fink SP, Marnett LJ, Muhle SA, Guengerich FP. Misincorporation of nucleotides opposite five-membered exocyclic ring guanine derivatives by escherichia coli polymerases in vitro and in vivo: 1,N2-ethenoguanine, 5,6,7,9-tetrahydro- 
9-oxoimidazo[1, 2-a]purine, and 5,6,7,9-tetrahydro-7-hydroxy-9-oxoimidazo[1, 2-a]purine. Biochemistry 1998;37:5184-5193

[62] Cheng KC, Preston BD, Cahill DS, Dosanjh MK, Singer B, Loeb LA. The vinyl chloride DNA derivative N2,3-ethenoguanine produces G----A transitions in Escherichia coli. Proc Natl Acad Sci U S A 1991;88:9974-9978

[63] Langouet S, Muller M, Guengerich FP. Misincorporation of dNTPs opposite 1,N2ethenoguanine and 5,6,7,9-tetrahydro-7-hydroxy-9-oxoimidazo[1,2-a]purine in oligonucleotides by Escherichia coli polymerases I exo- and II exo-, T7 polymerase exo-, human immunodeficiency virus-1 reverse transcriptase, and rat polymerase beta.

Biochemistry 1997;36:6069-6079

[64] Bartsch H, Barbin A, Marion MJ, Nair J, Guichard Y. Formation, detection, and role in carcinogenesis of ethenobases in DNA. Drug Metab Rev 1994;26:349-371

[65] Sabourin M, Osheroff N. Sensitivity of human type II topoisomerases to DNA damage: stimulation of enzyme-mediated DNA cleavage by abasic, oxidized and alkylated lesions. Nucleic Acids Res 2000;28:1947-1954

[66] Benamira M, Marnett LJ. The lipid peroxidation product 4-hydroxynonenal is a potent inducer of the SOS response. Mutat Res 1992;293:1-10

[67] Janowska B, Kurpios-Piec D, Prorok P, Szparecki G, Komisarski M, Kowalczyk P, Janion C, Tudek B. Role of damage-specific DNA polymerases in M13 phage mutagenesis induced by a major lipid peroxidation product trans-4-hydroxy-2-nonenal. Mutat Res 2011; [68] Nair J, Barbin A, Velic I, Bartsch H. Etheno DNA-base adducts from endogenous reactive species. Mutat Res 1999;424:59-69

[69] Nair J, Sone H, Nagao M, Barbin A, Bartsch H. Copper-dependent formation of miscoding etheno-DNA adducts in the liver of Long Evans cinnamon (LEC) rats developing hereditary hepatitis and hepatocellular carcinoma. Cancer Res 1996;56:1267-1271 
[70] Nair J, Sinitsina O, Vasunina EA, Nevinsky GA, Laval J, Bartsch H. Age-dependent increase of etheno-DNA-adducts in liver and brain of ROS overproducing OXYS rats. Biochem Biophys Res Commun 2005;336:478-482

[71] Nair J, Carmichael PL, Fernando RC, Phillips DH, Strain AJ, Bartsch H. Lipid peroxidation-induced etheno-DNA adducts in the liver of patients with the genetic metal storage disorders Wilson's disease and primary hemochromatosis. Cancer Epidemiol Biomarkers Prev 1998;7:435-440

[72] Pang B, Zhou X, Yu H, Dong M, Taghizadeh K, Wishnok JS, Tannenbaum SR, Dedon PC. Lipid peroxidation dominates the chemistry of DNA adduct formation in a mouse model of inflammation. Carcinogenesis 2007;28:1807-1813

[73] Nair U, Bartsch H, Nair J. Lipid peroxidation-induced DNA damage in cancer-prone inflammatory diseases: a review of published adduct types and levels in humans. Free Radic Biol Med 2007;43:1109-1120

[74] Nair J, Furstenberger G, Burger F, Marks F, Bartsch H. Promutagenic etheno-DNA adducts in multistage mouse skin carcinogenesis: correlation with lipoxygenase-catalyzed arachidonic acid metabolism. Chem Res Toxicol 2000;13:703-709

[75] Bartsch H, Nair J. Chronic inflammation and oxidative stress in the genesis and perpetuation of cancer: role of lipid peroxidation, DNA damage, and repair. Langenbecks Arch Surg 2006;391:499-510

[76] Federico A, Morgillo F, Tuccillo C, Ciardiello F, Loguercio C. Chronic inflammation and oxidative stress in human carcinogenesis. Int J Cancer 2007;121:2381-2386

[77] Shuck SC, Short EA, Turchi JJ. Eukaryotic nucleotide excision repair: from understanding mechanisms to influencing biology. Cell Res 2008;18:64-72 
[78] Pardo B, Gomez-Gonzalez B, Aguilera A. DNA repair in mammalian cells: DNA double-strand break repair: how to fix a broken relationship. Cell Mol Life Sci 2009;66:10391056

[79] Eker AP, Quayle C, Chaves I, van der Horst GT. DNA repair in mammalian cells: Direct DNA damage reversal: elegant solutions for nasty problems. Cell Mol Life Sci 2009;66:968980

[80] Fortini P, Dogliotti E. Base damage and single-strand break repair: mechanisms and functional significance of short- and long-patch repair subpathways. DNA Repair (Amst) $2007 ; 6: 398-409$

[81] Almeida KH, Sobol RW. A unified view of base excision repair: lesion-dependent protein complexes regulated by post-translational modification. DNA Repair (Amst) 2007;6:695-711

[82] Hegde ML, Hazra TK, Mitra S. Early steps in the DNA base excision/single-strand interruption repair pathway in mammalian cells. Cell Res 2008;18:27-47

[83] Robertson AB, Klungland A, Rognes T, Leiros I. DNA repair in mammalian cells: Base excision repair: the long and short of it. Cell Mol Life Sci 2009;66:981-993

[84] Saparbaev M, Kleibl K, Laval J. Escherichia coli, Saccharomyces cerevisiae, rat and human 3-methyladenine DNA glycosylases repair 1,N6-ethenoadenine when present in DNA. Nucleic Acids Res 1995;23:3750-3755

[85] Saparbaev M, Laval J. 3,N4-ethenocytosine, a highly mutagenic adduct, is a primary substrate for Escherichia coli double-stranded uracil-DNA glycosylase and human mismatchspecific thymine-DNA glycosylase. Proc Natl Acad Sci U S A 1998;95:8508-8513

[86] Kavli B, Sundheim O, Akbari M, Otterlei M, Nilsen H, Skorpen F, Aas PA, Hagen L, Krokan HE, Slupphaug G. hUNG2 is the major repair enzyme for removal of uracil from U:A 
matches, U:G mismatches, and U in single-stranded DNA, with hSMUG1 as a broad specificity backup. J Biol Chem 2002;277:39926-39936

[87] Bellacosa A. Role of MED1 (MBD4) Gene in DNA repair and human cancer. J Cell Physiol 2001;187:137-144

[88] Jiricny J, Menigatti M. DNA Cytosine demethylation: are we getting close? Cell 2008;135:1167-1169

[89] Saparbaev M, Langouet S, Privezentzev CV, Guengerich FP, Cai H, Elder RH, Laval J. 1,N(2)-ethenoguanine, a mutagenic DNA adduct, is a primary substrate of Escherichia coli mismatch-specific uracil-DNA glycosylase and human alkylpurine-DNA-N-glycosylase. J Biol Chem 2002;277:26987-26993

[90] Privezentzev CV, Saparbaev M, Laval J. The HAP1 protein stimulates the turnover of human mismatch-specific thymine-DNA-glycosylase to process 3,N(4)-ethenocytosine residues. Mutat Res 2001;480-481:277-284

[91] Demple B, Sung JS. Molecular and biological roles of Ape1 protein in mammalian base excision repair. DNA Repair (Amst) 2005;4:1442-1449

[92] Um S, Harbers M, Benecke A, Pierrat B, Losson R, Chambon P. Retinoic acid receptors interact physically and functionally with the T:G mismatch-specific thymine-DNA glycosylase. J Biol Chem 1998;273:20728-20736

[93] Tini M, Benecke A, Um SJ, Torchia J, Evans RM, Chambon P. Association of CBP/p300 acetylase and thymine DNA glycosylase links DNA repair and transcription. Mol Cell $2002 ; 9: 265-277$

[94] Missero C, Pirro MT, Simeone S, Pischetola M, Di Lauro R. The DNA glycosylase T:G mismatch-specific thymine DNA glycosylase represses thyroid transcription factor-1activated transcription. J Biol Chem 2001;276:33569-33575 
[95] Gros L, Maksimenko AV, Privezentzev CV, Laval J, Saparbaev MK. Hijacking of the human alkyl-N-purine-DNA glycosylase by 3,N4-ethenocytosine, a lipid peroxidationinduced DNA adduct. J Biol Chem 2004;279:17723-17730

[96] Bartsch H, Nair J. Oxidative stress and lipid peroxidation-derived DNA-lesions in inflammation driven carcinogenesis. Cancer Detect Prev 2004;28:385-391

[97] Speina E, Zielinska M, Barbin A, Gackowski D, Kowalewski J, Graziewicz MA, Siedlecki JA, Olinski R, Tudek B. Decreased repair activities of 1,N(6)-ethenoadenine and 3,N(4)-ethenocytosine in lung adenocarcinoma patients. Cancer Res 2003;63:4351-4357 [98] Gackowski D, Speina E, Zielinska M, Kowalewski J, Rozalski R, Siomek A, Paciorek T, Tudek B, Olinski R. Products of oxidative DNA damage and repair as possible biomarkers of susceptibility to lung cancer. Cancer Res 2003;63:4899-4902

[99] Obtulowicz T, Winczura A, Speina E, Swoboda M, Janik J, Janowska B, Ciesla JM, Kowalczyk P, Jawien A, Gackowski D, Banaszkiewicz Z, Krasnodebski I, Chaber A, Olinski R, Nair J, Bartsch H, Douki T, Cadet J, Tudek B. Aberrant repair of etheno-DNA adducts in leukocytes and colon tissue of colon cancer patients. Free Radic Biol Med 2010;49:10641071

[100] Liu BQ, Wu YD, Li PH, Wei JX, Zhang T, Liu RL. Prostate cancer antigen-1 as a potential novel marker for prostate cancer. Asian J Androl 2007;9:821-826

[101] Konishi N, Nakamura M, Ishida E, Shimada K, Mitsui E, Yoshikawa R, Yamamoto H, Tsujikawa K. High expression of a new marker PCA-1 in human prostate carcinoma. Clin Cancer Res 2005;11:5090-5097

[102] Aravind L, Koonin EV. The DNA-repair protein AlkB, EGL-9, and leprecan define new families of 2-oxoglutarate- and iron-dependent dioxygenases. Genome Biol 2001;2:RESEARCH0007 
[103] Delaney JC, Smeester L, Wong C, Frick LE, Taghizadeh K, Wishnok JS, Drennan CL, Samson LD, Essigmann JM. AlkB reverses etheno DNA lesions caused by lipid oxidation in vitro and in vivo. Nat Struct Mol Biol 2005;12:855-860

[104] Mishina Y, Yang CG, He C. Direct repair of the exocyclic DNA adduct 1,N6ethenoadenine by the DNA repair AlkB proteins. J Am Chem Soc 2005;127:14594-14595 [105] Maciejewska AM, Ruszel KP, Nieminuszczy J, Lewicka J, Sokolowska B, Grzesiuk E, Kusmierek JT. Chloroacetaldehyde-induced mutagenesis in Escherichia coli: the role of AlkB protein in repair of 3,N(4)-ethenocytosine and 3,N(4)-alpha-hydroxyethanocytosine. Mutat Res 684:24-34

[106] Aas PA, Otterlei M, Falnes PO, Vagbo CB, Skorpen F, Akbari M, Sundheim O, Bjoras M, Slupphaug G, Seeberg E, Krokan HE. Human and bacterial oxidative demethylases repair alkylation damage in both RNA and DNA. Nature 2003;421:859-863

[107] Begley TJ, Samson LD. AlkB mystery solved: oxidative demethylation of N1methyladenine and N3-methylcytosine adducts by a direct reversal mechanism. Trends Biochem Sci 2003;28:2-5

[108] Falnes PO. Repair of 3-methylthymine and 1-methylguanine lesions by bacterial and human AlkB proteins. Nucleic Acids Res 2004;32:6260-6267

[109] Koivisto P, Duncan T, Lindahl T, Sedgwick B. Minimal methylated substrate and extended substrate range of Escherichia coli AlkB protein, a 1-methyladenine-DNA dioxygenase. J Biol Chem 2003;278:44348-44354

[110] Ougland R, Zhang CM, Liiv A, Johansen RF, Seeberg E, Hou YM, Remme J, Falnes PO. AlkB restores the biological function of mRNA and tRNA inactivated by chemical methylation. Mol Cell 2004;16:107-116

[111] Kurowski MA, Bhagwat AS, Papaj G, Bujnicki JM. Phylogenomic identification of five new human homologs of the DNA repair enzyme AlkB. BMC Genomics 2003;4:48 
[112] Gerken T, Girard CA, Tung YC, Webby CJ, Saudek V, Hewitson KS, Yeo GS, McDonough MA, Cunliffe S, McNeill LA, Galvanovskis J, Rorsman P, Robins P, Prieur X, Coll AP, Ma M, Jovanovic Z, Farooqi IS, Sedgwick B, Barroso I, Lindahl T, Ponting CP, Ashcroft FM, O'Rahilly S, Schofield CJ. The obesity-associated FTO gene encodes a 2oxoglutarate-dependent nucleic acid demethylase. Science 2007;318:1469-1472 [113] Yi C, Yang CG, He C. A non-heme iron-mediated chemical demethylation in DNA and RNA. Acc Chem Res 2009;42:519-529

[114] Duncan T, Trewick SC, Koivisto P, Bates PA, Lindahl T, Sedgwick B. Reversal of DNA alkylation damage by two human dioxygenases. Proc Natl Acad Sci U S A 2002;99:16660-16665

[115] Falnes PO, Bjoras M, Aas PA, Sundheim O, Seeberg E. Substrate specificities of bacterial and human AlkB proteins. Nucleic Acids Res 2004;32:3456-3461

[116] Mishina Y, Lee CH, He C. Interaction of human and bacterial AlkB proteins with DNA as probed through chemical cross-linking studies. Nucleic Acids Res 2004;32:1548-1554

[117] Ringvoll J, Moen MN, Nordstrand LM, Meira LB, Pang B, Bekkelund A, Dedon PC, Bjelland S, Samson LD, Falnes PO, Klungland A. AlkB homologue 2-mediated repair of ethenoadenine lesions in mammalian DNA. Cancer Res 2008;68:4142-4149

[118] Fu D, Samson LD. Direct repair of 3,N(4)-ethenocytosine by the human ALKBH2 dioxygenase is blocked by the AAG/MPG glycosylase. DNA Repair (Amst) [119] Gilljam KM, Feyzi E, Aas PA, Sousa MM, Muller R, Vagbo CB, Catterall TC, Liabakk NB, Slupphaug G, Drablos F, Krokan HE, Otterlei M. Identification of a novel, widespread, and functionally important PCNA-binding motif. J Cell Biol 2009;186:645-654 [120] Ringvoll J, Nordstrand LM, Vagbo CB, Talstad V, Reite K, Aas PA, Lauritzen KH, Liabakk NB, Bjork A, Doughty RW, Falnes PO, Krokan HE, Klungland A. Repair deficient 
mice reveal $\mathrm{mABH} 2$ as the primary oxidative demethylase for repairing $1 \mathrm{meA}$ and $3 \mathrm{meC}$ lesions in DNA. Embo J 2006;25:2189-2198

[121] Westbye MP, Feyzi E, Aas PA, Vagbo CB, Talstad VA, Kavli B, Hagen L, Sundheim O, Akbari M, Liabakk NB, Slupphaug G, Otterlei M, Krokan HE. Human AlkB homolog 1 is a mitochondrial protein that demethylates 3-methylcytosine in DNA and RNA. J Biol Chem 2008;283:25046-25056

[122] Muller TA, Meek K, Hausinger RP. Human AlkB homologue 1 (ABH1) exhibits DNA lyase activity at abasic sites. DNA Repair (Amst) 9:58-65

[123] Jia G, Yang CG, Yang S, Jian X, Yi C, Zhou Z, He C. Oxidative demethylation of 3methylthymine and 3-methyluracil in single-stranded DNA and RNA by mouse and human FTO. FEBS Lett 2008;582:3313-3319

[124] Jia G, Fu Y, Zhao X, Dai Q, Zheng G, Yang Y, Yi C, Lindahl T, Pan T, Yang YG, He C. N6-Methyladenosine in nuclear RNA is a major substrate of the obesity-associated FTO. Nat Chem Biol 2011;7:885-887

[125] Songe-Moller L, van den Born E, Leihne V, Vagbo CB, Kristoffersen T, Krokan HE, Kirpekar F, Falnes PO, Klungland A. Mammalian ALKBH8 possesses tRNA methyltransferase activity required for the biogenesis of multiple wobble uridine modifications implicated in translational decoding. Mol Cell Biol 30:1814-1827 [126] Begley U, Dyavaiah M, Patil A, Rooney JP, DiRenzo D, Young CM, Conklin DS, Zitomer RS, Begley TJ. Trm9-catalyzed tRNA modifications link translation to the DNA damage response. Mol Cell 2007;28:860-870

[127] Leihne V, Kirpekar F, Vagbo CB, van den Born E, Krokan HE, Grini PE, Meza TJ, Falnes PO. Roles of Trm9- and ALKBH8-like proteins in the formation of modified wobble uridines in Arabidopsis tRNA. Nucleic Acids Res 39:7688-7701 
[128] Pan Z, Sikandar S, Witherspoon M, Dizon D, Nguyen T, Benirschke K, Wiley C, Vrana P, Lipkin SM. Impaired placental trophoblast lineage differentiation in Alkbh1(-/-) mice. Dev Dyn 2008;237:316-327

[129] Shimada K, Nakamura M, Ishida E, Higuchi T, Yamamoto H, Tsujikawa K, Konishi N. Prostate cancer antigen-1 contributes to cell survival and invasion though discoidin receptor 1 in human prostate cancer. Cancer Sci 2008;99:39-45

[130] Tsujikawa K, Koike K, Kitae K, Shinkawa A, Arima H, Suzuki T, Tsuchiya M, Makino Y, Furukawa T, Konishi N, Yamamoto H. Expression and sub-cellular localization of human ABH family molecules. J Cell Mol Med 2007;11:1105-1116

[131] Hu W, Feng Z, Eveleigh J, Iyer G, Pan J, Amin S, Chung FL, Tang MS. The major lipid peroxidation product, trans-4-hydroxy-2-nonenal, preferentially forms DNA adducts at codon 249 of human p53 gene, a unique mutational hotspot in hepatocellular carcinoma.

Carcinogenesis 2002;23:1781-1789

[132] Feng Z, Hu W, Amin S, Tang MS. Mutational spectrum and genotoxicity of the major lipid peroxidation product, trans-4-hydroxy-2-nonenal, induced DNA adducts in nucleotide excision repair-proficient and -deficient human cells. Biochemistry 2003;42:7848-7854 [133] Esterbauer H, Eckl P, Ortner A. Possible mutagens derived from lipids and lipid precursors. Mutat Res 1990;238:223-233

[134] Eckl PM, Ortner A, Esterbauer H. Genotoxic properties of 4-hydroxyalkenals and analogous aldehydes. Mutat Res 1993;290:183-192

[135] Karlhuber GM, Bauer HC, Eckl PM. Cytotoxic and genotoxic effects of 4hydroxynonenal in cerebral endothelial cells. Mutat Res 1997;381:209-216 [136] Huang H, Wang H, Kozekova A, Rizzo CJ, Stone MP. Formation of a N2-dG:N2-dG carbinolamine DNA cross-link by the trans-4-hydroxynonenal-derived (6S,8R,11S) 1,N2-dG adduct. J Am Chem Soc 133:16101-16110 
[137] Maddukuri L, Speina E, Christiansen M, Dudzinska D, Zaim J, Obtulowicz T,

Kabaczyk S, Komisarski M, Bukowy Z, Szczegielniak J, Wojcik A, Kusmierek JT, Stevnsner

T, Bohr VA, Tudek B. Cockayne syndrome group B protein is engaged in processing of DNA adducts of lipid peroxidation product trans-4-hydroxy-2-nonenal. Mutat Res 2009;666:23-31

[138] Tornaletti S. Transcription arrest at DNA damage sites. Mutat Res 2005;577:131-145

[139] Licht CL, Stevnsner T, Bohr VA. Cockayne syndrome group B cellular and biochemical functions. Am J Hum Genet 2003;73:1217-1239

[140] Zarkovic K. 4-hydroxynonenal and neurodegenerative diseases. Mol Aspects Med $2003 ; 24: 293-303$

[141] Hayashi M, Itoh M, Araki S, Kumada S, Shioda K, Tamagawa K, Mizutani T, Morimatsu Y, Minagawa M, Oda M. Oxidative stress and disturbed glutamate transport in hereditary nucleotide repair disorders. J Neuropathol Exp Neurol 2001;60:350-356 [142] Feng Z, Hu W, Tang MS. Trans-4-hydroxy-2-nonenal inhibits nucleotide excision repair in human cells: a possible mechanism for lipid peroxidation-induced carcinogenesis. Proc Natl Acad Sci U S A 2004;101:8598-8602

[143] Kumar S, Kokate RA, Sahu M, Chaudhary P, Sharma R, Awasthi S, Awasthi YC. Inhibition of mercapturic acid pathway-mediated disposal of 4-hydroxynonenal causes complete and sustained remission of human cancer xenografts in nude mice. Indian J Exp Biol $49: 817-825$

[144] Pizzimenti S, Menegatti E, Berardi D, Toaldo C, Pettazzoni P, Minelli R, Giglioni B, Cerbone A, Dianzani MU, Ferretti C, Barrera G. 4-hydroxynonenal, a lipid peroxidation product of dietary polyunsaturated fatty acids, has anticarcinogenic properties in colon carcinoma cell lines through the inhibition of telomerase activity. J Nutr Biochem 2010;21:818-826 
[145] Pizzimenti S, Briatore F, Laurora S, Toaldo C, Maggio M, De Grandi M, Meaglia L, Menegatti E, Giglioni B, Dianzani MU, Barrera G. 4-Hydroxynonenal inhibits telomerase activity and hTERT expression in human leukemic cell lines. Free Radic Biol Med 2006;40:1578-1591

[146] Schmid K, Nair J, Winde G, Velic I, Bartsch H. Increased levels of promutagenic etheno-DNA adducts in colonic polyps of FAP patients. Int J Cancer 2000;87:1-4 [147] Nair J, Gansauge F, Beger H, Dolara P, Winde G, Bartsch H. Increased etheno-DNA adducts in affected tissues of patients suffering from Crohn's disease, ulcerative colitis, and chronic pancreatitis. Antioxid Redox Signal 2006;8:1003-1010 
Table 1. DNA ethenoadducts levels in various human diseases.

\begin{tabular}{|c|c|c|c|c|}
\hline Disease & $\begin{array}{c}\text { Affected } \\
\text { organ }\end{array}$ & $\begin{array}{c}\text { Absolute values of } \\
\text { ethenoadducts per } 10^{9} \\
\text { parent nucleotides }\end{array}$ & $\begin{array}{c}\text { Fold increase of } \\
\text { DNA } \\
\text { ethenoadducts }\end{array}$ & Reference \\
\hline Wilson's disease & Liver & $\begin{array}{c}\varepsilon A-61.03 \pm 7.95 \\
\varepsilon C-91.50 \pm 36.02\end{array}$ & $\begin{array}{l}3 \varepsilon \mathrm{A}, 3 \mathrm{\varepsilon C} \\
\text { in comparison to } \\
\text { normal liver }\end{array}$ & [71] \\
\hline $\begin{array}{l}\text { Primary } \\
\text { hemochromatosis }\end{array}$ & Liver & $\begin{array}{l}\varepsilon A-46.62 \pm 32.83 \\
\varepsilon C-64.32 \pm 11.55\end{array}$ & $\begin{array}{l}2 \varepsilon \mathrm{A}, 2 \mathrm{\varepsilon C} \\
\text { in comparison to } \\
\text { normal liver }\end{array}$ & [71] \\
\hline $\begin{array}{l}\text { Familial adenomatous } \\
\text { polyposis }\end{array}$ & $\begin{array}{l}\text { Colon } \\
\text { polyps }\end{array}$ & $\begin{array}{l}\varepsilon A-65.3 \\
\varepsilon C-31.4\end{array}$ & $\begin{array}{l}2 \varepsilon \mathrm{A}, 2 \mathrm{\varepsilon C} \\
\text { in comparison to } \\
\text { unaffected colon }\end{array}$ & [146] \\
\hline Crohn's disease & Colon & $\varepsilon C-325 \pm 346$ & $\begin{array}{l}20 \varepsilon \mathrm{C} \\
\text { in comparison to } \\
\text { asymptomatic } \\
\text { colon }\end{array}$ & [147] \\
\hline Ulcerative colitis & Colon & $\varepsilon C-69 \pm 36$ & $\begin{array}{l}4 \varepsilon \mathrm{C} \\
\text { in comparison to } \\
\text { asymptomatic } \\
\text { colon }\end{array}$ & [147] \\
\hline Chronic pancreatitis & Pancreas & $\begin{array}{c}\varepsilon A-63 \pm 56 \\
\varepsilon C-354 \pm 251\end{array}$ & $\begin{array}{l}3 \varepsilon \mathrm{A}, 28 \varepsilon \mathrm{C} \\
\text { in comparison to } \\
\text { normal pancreas }\end{array}$ & [147] \\
\hline
\end{tabular}




\section{Figure 1. Pathways of lipid peroxidation.}

Figure 2. Structures of LPO-derived reactive aldehydes (according to [7]). Left panelgeneral structures, right panel- examples of reactive aldehydes that belong to particular families, HHE- 4-hydroxy-2-hexenal, HNE- 4-hydroxy-2-nonenal, MDA- malondialdehyde, ONE- 4-oxo-2-nonenal.

Figure 3. Mechanisms of HNE formation (according to [17]). A-from 9-hydroxyperoxyoctadecenoic acid (9(S)-HPODE) as a precursor; B- from 13-hydroxyperoxy-octadecenoic acid (13(S)-HPODE) as a precursor.

Figure 4. Michael addition of thiols (according to [10]).

Figure 5. Schiff-base formation with primary amines (according to [10]).

Figure 6. The major exocyclic DNA adducts. $\mathrm{M}_{1} \mathrm{dG}, 1, N^{2}$-ethenoguanine $\left(1, N^{2}-\varepsilon \mathrm{G}\right), N^{2}, 3-$ ethenoguanine $\left(N^{2}, 3 \varepsilon \mathrm{G}\right), 3, N^{4}$-ethenocytosine $(\varepsilon \mathrm{C}), 1, N^{6}$-ethenoadenine $(\varepsilon \mathrm{A})$.

Figure 7. Interaction of HNE with deoxyguanosine.

Figure 8. Interaction of HNE epoxide with deoxyguanosine.

Figure 9. AlkB mechanism of direct reversal. 


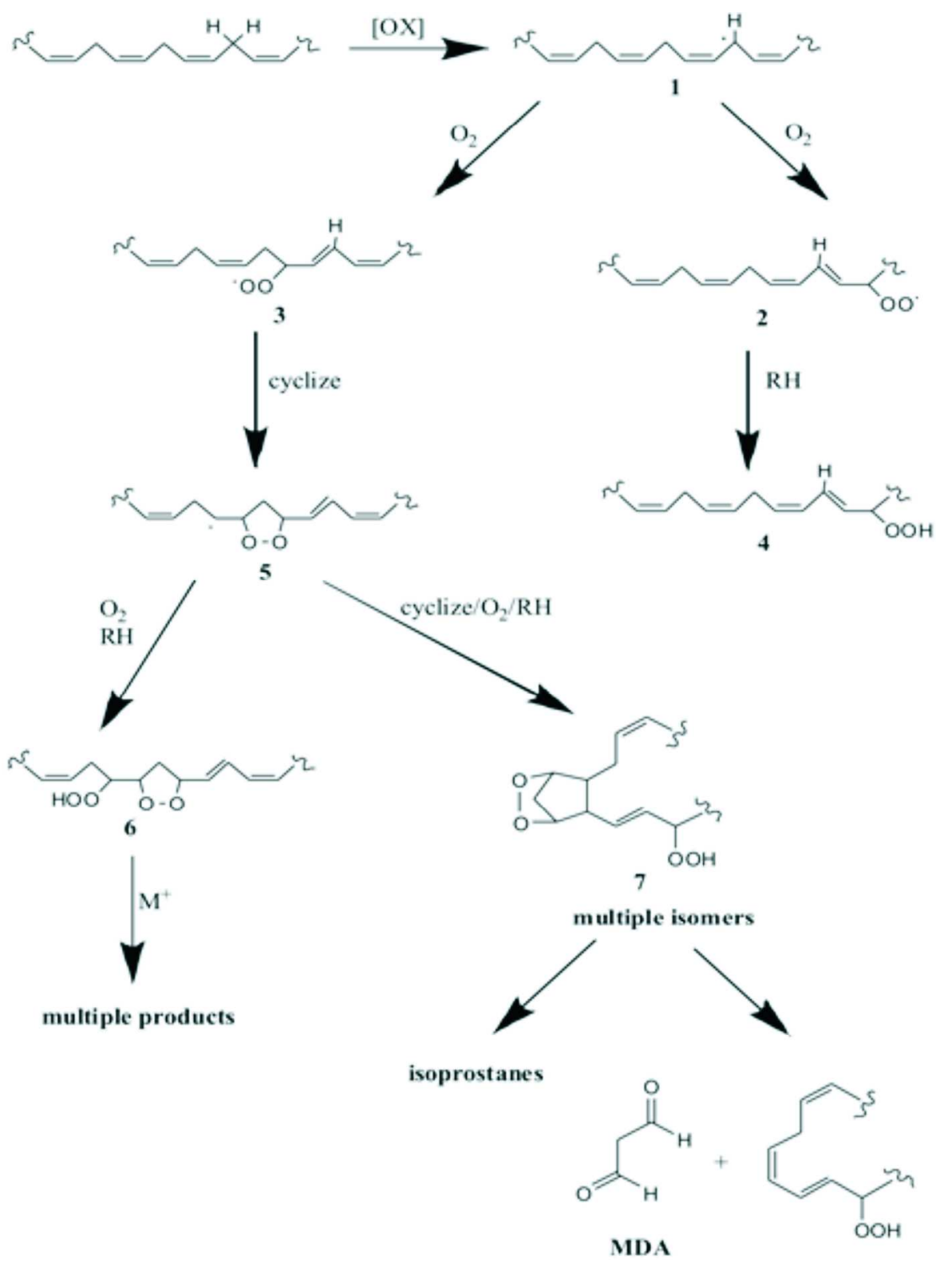

Figure 1. Pathways of lipid peroxidation $153 \times 204 \mathrm{~mm}(300 \times 300$ DPI $)$ 
Figure 2. Structures of LPO-derived reactive aldehydes (according to [7]). Left panel- general structures, right panel- examples of reactive aldehydes that belong to particular families, HHE- 4-hydroxy-2-hexenal, HNE- 4-hydroxy-2-nonenal, MDA- malondialdehyde, ONE- 4-oxo-2-nonenal $59 \times 24 \mathrm{~mm}(300 \times 300 \mathrm{DPI})$ 
Figure 3. Mechanisms of HNE formation (according to [11]). A-from 9-hydroxyperoxy-octadecenoic acid (9(S)-HPODE) as a precursor; B- from 13-hydroxyperoxy-octadecenoic acid (13(S)-HPODE) as a precursor. $117 \times 93 \mathrm{~mm}(300 \times 300 \mathrm{DPI})$ 


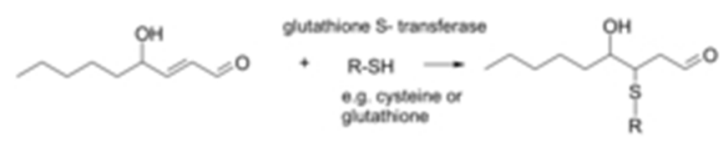

Figure 4. Michael addition of HNE to thiols (according to [10]) $23 \times 4 \mathrm{~mm}(300 \times 300 \mathrm{DPI})$ 


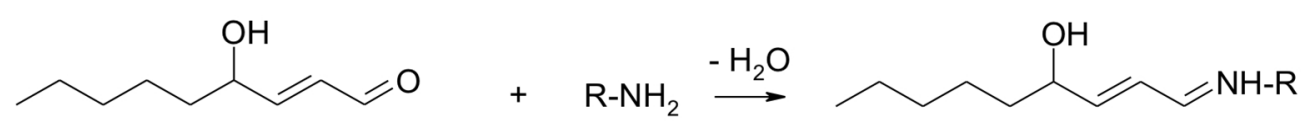

Figure 5. Schiff-base formation with primary amines (according to [10]) $132 \times 11 \mathrm{~mm}(300 \times 300 \mathrm{DPI})$ 
1

2

3

4

5

6

7

8

9

10

11

12

13

14

15

16

17

18

19

20

21

22

23

24

25

26

27

28

29

30

31

32

33

34

35

36

37

38

39

40

41

42

43

44

45

46

47

48

49

50

51

52

53

54

55

56

57

58

59

60<smiles>Nn1cnc2c(=O)n3c(O)ccnc3nc21</smiles>

M1dG<smiles>O=c1c2ncn(-n3cccc3)c2nc2[nH]ccn12</smiles><smiles>N#[Y10]n1cnc2c(=O)[nH]c3nccn3c21</smiles>

\section{1, $N^{2}$-ethenoguanine $\quad N^{2}, 3$-ethenoguanine}<smiles>O=c1n([18O])ccc2nccn12</smiles><smiles>Cn1cnc2c1ncn1ccnc21</smiles>

DNA

\section{3,N4-ethenocytosine \\ $1, N^{6}$-ethenoadenine}

Figure 6. Major modifications of DNA bases by LPO products. M1dG, 1,N2-ethenoguanine (1,N2- $\varepsilon \mathrm{G}), \mathrm{N} 2,3-$ ethenoguanine $(\mathrm{N} 2,3-\varepsilon \mathrm{G}), 3$, N4-ethenocytosine $(\varepsilon \mathrm{C})$, 1,N6-ethenoadenine $(\varepsilon A)$ $99 \times 73 \mathrm{~mm}(300 \times 300 \mathrm{DPI})$ 

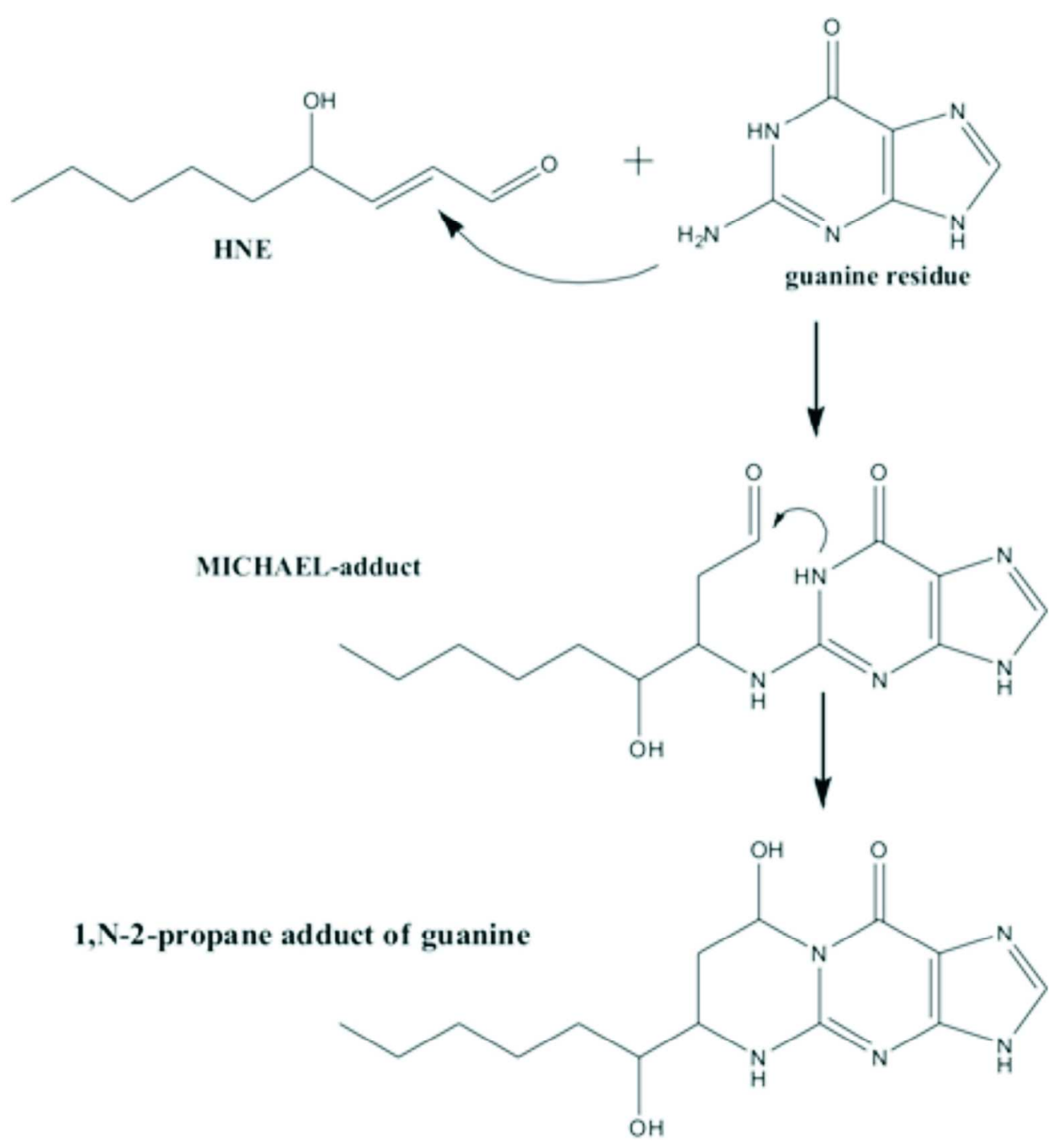

Figure 7. Interaction of HNE with deoxyguanosine $123 \times 133 \mathrm{~mm}$ ( $300 \times 300$ DPI) 


\section{$1, \mathrm{~N}^{2}$-etheno adduct of guanosine} epoxide of HNE

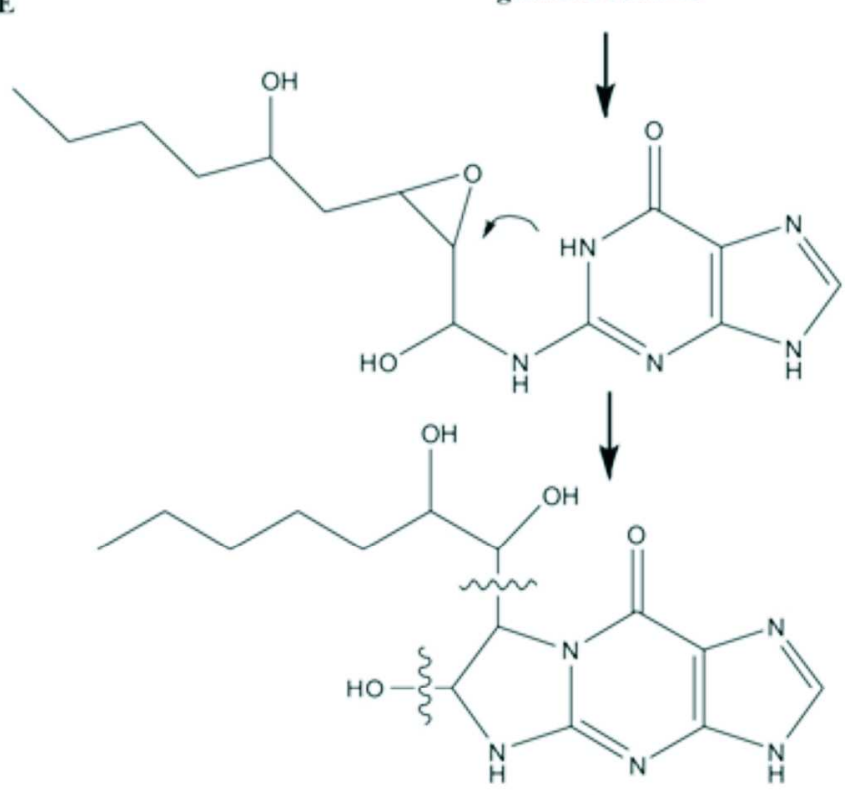<smiles>CCCCCC(O)C=O</smiles><smiles>O=c1c2nc[nH]c2nc2[nH]ccn12</smiles>

Figure 8. Interaction of HNE epoxide with deoxyguanosine $173 \times 227 \mathrm{~mm}(300 \times 300$ DPI $)$ 


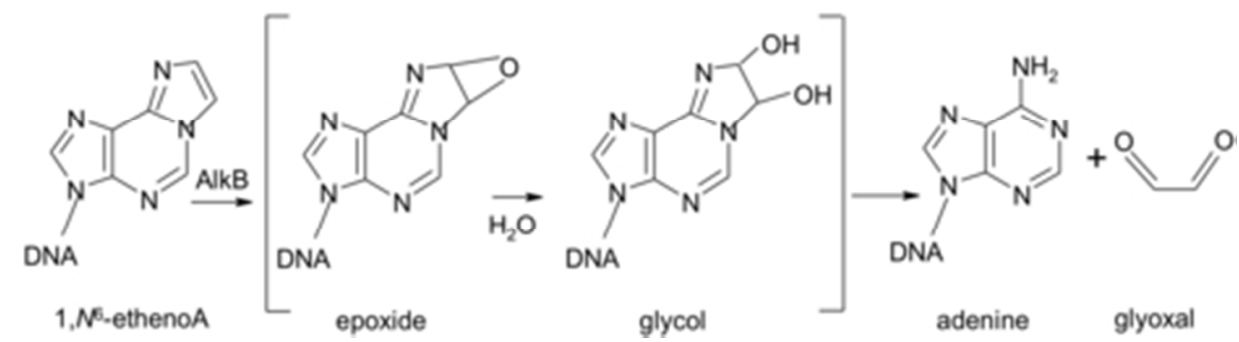

Figure 9. The mechanism of oxidative dealkylation of DNA bases by AlkB proteins $39 \times 10 \mathrm{~mm}(300 \times 300 \mathrm{DPI})$ 